Article

\title{
Magicians, Sorcerers and Witches: Considering Pretantric, Non-sectarian Sources of Tantric Practices
}

\author{
Ronald M. Davidson \\ Department of Religious Studies, Farifield University, Fairfield, CT 06824, USA; rdavidson@fairfield.edu \\ Received: 27 June 2017; Accepted: 23 August 2017; Published: 13 September 2017
}

\begin{abstract}
Most models on the origins of tantrism have been either inattentive to or dismissive of non-literate, non-sectarian ritual systems. Groups of magicians, sorcerers or witches operated in India since before the advent of tantrism and continued to perform ritual, entertainment and curative functions down to the present. There is no evidence that they were tantric in any significant way, and it is not clear that they were concerned with any of the liberation ideologies that are a hallmark of the sectarian systems, even while they had their own separate identities and specific divinities. This paper provides evidence for the durability of these systems and their continuation as sources for some of the ritual and nomenclature of the sectarian tantric traditions, including the predisposition to ritual creativity and bricolage.
\end{abstract}

Keywords: tantra; mantra; ritual; magician; sorcerer; seeress; vidyādhara; māyākāra; aindrajālika; non-literate

\section{Introduction ${ }^{1}$}

In the emergence of alternative religious systems such as tantrism, a number of factors have historically been seen at play. Among these are elements that might be called 'pre-existing'. That is, they themselves are not representative of the eventual emergent system, but they provide some of the raw material—ritual, ideological, terminological, functional, or other-for its development. Indology, and in particular the study of Indian ritual, has been less than adroit at discussing such phenomena, especially when it may be designated or classified as 'magical' in some sense. The social fact of several categories of individuals either referencing themselves or being referenced by others as magicians, sorcerers, witches or seers, and pursuing livelihoods by those means in ancient, medieval and modern India is a reality worthy of investigation, given the observable contribution of these groups to the eventual emergence of tantrism in the sixth or seventh century. They do not appear to have expressed ideologies of liberation or transcendent divinity but were concerned with magical crafts of various kinds. Such groups not only preceded the formation of sectarian, lineage-based tantrism by well over a millennium, but they also continued to function outside of formal tantric structures until the present-a poorly studied and under-recognized reality of Indian social and religious life.

This paper will argue that some of the dynamics and ritual practices of Indian magicians and sorcerers were appropriated by tantric groups, so that later forms still exhibit analogous attributes. Thus, various kinds of magicians and illusionists contribute some (out of many) source streams for social and ritual praxis, as well as magical nomenclature, both of which were appropriated by the tantric traditions on an as-need basis. The intermittent and idiosyncratic nature of the appropriation seems also to be a property of the earlier groups, and perhaps contributed to the tantric predisposition toward textual or ritual bricolage.

1 Some of this material I have presented previously in various venues, including the Tantra-Agama panel at the 14th World Sanskrit Conference in Kyoto, 2009, invited by Dominic Goodall and Einoo Shingo. 


\section{Problematic Historical Representations}

Those having even a modest familiarity with scholarly literature on the contested origins of tantrism may see that there are several problematic positions that have skewed our understanding, and in some measure these positions are related. First, and most important, there is the supposition that the origins of tantrism are grounded in elite, intellectual formulae. In this model, the renowned hermeneutists and theologians within the various sectarian orders-Śaiva, Vaiṣnava, Buddhist, Jain or other-represent the authentic voices and irrefutable sources of tantrism, and the roots of this movement is best understood by examining their archive. For some scholars, this includes the model that tantrism is an intellectual project formulated in diametric opposition to the dominant paradigm, inverting it, so that antinomian or alternative practices are but contradictions of the dharmasūtra dicta.

Second, because there is by definition no surviving literature attributable to non-literate traditions, such individuals cannot be reasonably postulated (Sanderson 1994, p. 92). ${ }^{2}$ Third, as authentic tantric sources must be grounded only in literate intellectualist textual traditions, any reports about alternative, non-literate groups must be considered fallacious or inconsequential (Wedemeyer 2013, p. 196). Fourth, such positions have been in some measure configured by questions of lineage and sectarian ideology, predominantly focused on literate traditions that survive to this day, in which one or another of them claim priority in order to depict all others as derivative. In this model, one of the modern sectarian systems of tantrism makes the claim of first invention, and the method of dissemination is diffusion, whether textually or by some other means. ${ }^{3}$

While there certainly is a relationship between tantrism and the pre-existent intellectual, theological, legal and ritual literature of India, it still may appear to those informed on the history of alternative or emergent religious movements, that the unarguably later intellectual elites constitute a second-order phenomenon, in other contexts identified as "rationalized religion" by Weber. ${ }^{4}$ Such rationalized functions are extremely important for the development of hermeneutics and theology, but it is difficult to identify them as the principal sources of the differing traditions, which tend to be grounded in social disruption rather than in an act of intellectual imagination. ${ }^{5}$ Nor can much of tantrism be understood by a simple inversion of the "Vedic tradition" or the dharmasutras (although both are actually manifold) for that would not yield the majority of tantric practices. ${ }^{6}$ Moreover,

2 This is in response to an earlier version of Ruegg's well-known "religious substratum" argument, which he again put forward at a later date, (Ruegg 2007). Sanderson's method has consistently been to presume written texts rather than oral texts, understandable but excessively limiting as a historical model. Already the model was shown to be problematic, as in the Śaiva and Buddhist appropriation of Tumburu from his position as a tree divinity (Griffiths 2004-2005); but there seem to be some reticence in acknowledging Griffith's discovery, even when Tumburu is discussed (e.g., (Sanderson 2009, pp. 46-7n13, 50-1n22, 129n301, 130)).

3 Fortunately, the issue of both textual borrowing and intertextuality (which are not the same) have received attention outside of claims of 'plagiarism', this latter idea invoking a post-enlightenment category for medieval texts. One recent volume devoted to this issue is Freschi and Maas (2017), which is dedicated to philosophical and hermeneutical issues rather than ritual ones.

4 Weber [1956] (Weber [1956] 1965, pp. 20-31) foregrounds the antagonism between religion and magic, with the idea that religion rationalizes and therefore marginalizes magic, analogous in some ways to what we see in the development of tantric hermeneutics; see also (Weber [1930] 2001, pp. 71-72, 86-88, 95-100). For a discussion of the subsequent scholarship on Weber's idea, and its application in venues other than religion, see (Sica 2000).

5 (Stark 2015, pp. 32-58, 149-209, 336-72). There are several analogs to the rise of tantrism, one being Marian devotionalism; see (Mitchell 2009). Another might be the formation of Kabbalah mysticism in 12th century Province; see (Scholem 1991); for the difference between the history of Kabbalah and its self-presentation in later hermeneutics, see (Yisraeli 2016). In India, similar functions are seen in the Lingayata tradition, the Kabir Panth and others. Most such alternative systems begin with a socio-religious movement and develop elaborate ideologies and hermeneutics at a later date, which is how I understand tantrism in general.

6 This is Wedemeyer's (Wedemeyer 2013, pp. 119, 188-92) claim. Unfortunately, his presentation of the relationship between tantric Buddhism, the different schools of dharmasūtra, the Vedic ritual systems (śākha), and the local decision-making procedures of Indian society at large cannot be recommended. For a sophisticated discussion of some of these issues, see (Lingat 1973, pp. 143-206); observing how they worked out in the context of late medieval Kerala, see (Davis 2004, pp. 119-47). To give but a couple of examples, if the inversion of dharmasutra categories were the leitmotif of tantrism, the early communities would have been run by women and outcastes, instead of promoting the non-observance of caste in the ganacakra. Similarly, if inversion were the motive, then disciples would be encouraged to seduce the teacher's wife, since 
as already pointed out by Blaut (1987) and others, unsophisticated diffusionist models similar to those proposed implicitly or explicitly encode a political position and covert hegemony, and certainly this seems apparent in many scholarly appeals to diffusion as the source of tantric textual similarity. Equally, it appears to me that a single source model, as exercised, is ladened with multiple fallacies of historical reasoning, assumptions concerning authenticity and other questionable suppositions. So, if all secondary forms are derivative, with the implication that they thereby are inauthentic, then the intellectual traditions could also be considered derivative and inauthentic, a curious entailment of the proposal. As a result, in order to model the rise and efflorescence of tantrism in all its manifold diversity, models positing an elite intellectual project followed by a subsequent diffusion to the lower strata are perhaps less cogent than claimed.

In terms of our available archive, I would like to argue that such models take little account of the multi-nodal form of the matrix of tantrism, the discrete socio-cultural network systems, which in my estimation were developed in the highly distributed ritual world of India from a plethora of points and sources, not just from one. An alternative multi-nodal or multi-source model could assume that pre-existent forms-which may continue on independently-have persistently contributed to tantric ideas and rituals over time. ${ }^{7}$ The corollary to this would be that tantric systems continued to reinvent themselves on a decade-by-decade basis, one of the reasons that an omnibus definition of tantrism per $s e$ is so elusive. Elements appropriated may be either integrated as ritual or textual pericope, but that appropriation occurs with a robust dynamic, and is neither unidirectional nor unilateral. The process resists essentialist presumptions, for the elements selectively either diffused or appropriated both change and are reinterpreted in new social and ideological horizons in the process. A multi-nodal and simultaneously emergent, distributed network system fits Indian reality more clearly than the modern Euro-American ideology of single-source independent invention, which is not even true in the Euro-American world. Specialists in the origins of Mahāyāna Buddhism have arrived at similar multi-nodal models in understanding the different factors-intellectual, literary, performative, soteriological and so on-which contributed to the Mahāyāna form of Buddhism evolving in the first to sixth centuries of the common era in highly distributed networks (e.g., the essays in (Nyanatusita himi 2013)). Analogous observations have been made about the purānas, the grhya-sütras, the epics, and other genres of Indian religious literature. In general, these models are consonant with the text-critical methods of form and redaction theory as well. ${ }^{8}$

In this paper, I would like to focus on one of the historiographical curiosities found in tantric studies, one that extends from the suppositions just mentioned: the desire for scholars to integrate prior religious outliers into forms known from literature of their specialization. Sometimes this is done with the relatively historical awareness that these previous outliers are not actually the later forms encapsulated in an earlier enterprise, anachronistically projected into the past. More frequently, however, we see a willingness to draw straight lines between one behavior, often of non-literate groups, and a later, generally literate, form of ritual or belief, neglecting the differences of social frame, operational function or symbolic formulation. Thus, the pattern established in a mature system is held as the standard, and the antecedent outlier system is shaped, sculpted, and sometimes forced

drinking liquor and seducing the guru's wife are found in the same place in many dharmasütras and even in the same rule: e.g., Viṣnusmṛti 35.1: brahmahatyā surāpānam brāhmaṇasuvarṇaharaṇaṃ gurudāragamanam iti mahāpātakāni || "Killing a brahman, drinking liquor, stealing the gold of a brahman, and going to the guru's wife-these are the great crimes causing loss of caste." Simply inverting the different, often contradictory, legal injunctions of either the dharmasūtras or the purānas or the grhyasütras does not yield tantrism, nor has Wedemeyer done more than select a few items to promote his thesis, ignoring a great mass of data that does not support his position.

7 The extensive literature and quantitative model construction based on issues of nodality and network theory are beyond the scope of this paper, but its applicability to archaeology has been summarized in Collar et al. (2015) and its use in Indian agrarian governance is explored in Udayaadithya and Gurtoo (2013).

8 Form-critical approaches are discussed in Sweeney and Zvi (2003), and historically assessed in Byrskog (2007); recent redaction-critical approaches are outlined in Tan (2001). Other text-critical approaches are emerging, but they generally presume a granulation of a text drawn from multiple sources. 
into a comfortable acquaintance in scholarly literature. This is the teleological fallacy, that the end known to us is encoded in the earlier form, a fallacy often accompanied with the quasi-Marxist idea that the earlier form embodies the seeds of its own destruction. Thus, the model is most often provided an addendum, in which the pre-existent outlier is "absorbed" into tantrism, with the inchoate presumption that Indian tantrism acted as a kind of religious singularity, operating in a manner so that nothing could escape its gravity.

Instead I would propose that these pre-existing, alternative behaviors had their own dynamics, although much is unknown based on the data available. Among my arguments will be the observation that we are often misled by Indological attachment to the lineages of the written texts, which indeed have their historical gravity precisely because they are written and conserved. Yet, when we compare Indological emphasis on literacy with the earliest remotely comprehensive census of India, the 1881 census, we may surmise how slight literacy must have been in the world in which tantrism emerged. The census concluded that, among the adult Hindu subjects, literacy was $6 \%$ range (about $12 \%$ of males, negligible females; (Plowden 1883, vol. 1, pp. 227-38)), a figure almost exactly confirmed in the 1891 census (Baines 1893, pp. 214-16). The authors of the imperial census were well aware-as we are in our census statistics today-that the disadvantaged classes were undercounted. Perhaps the actual literacy figure was in the neighborhood of $5 \%$ overall, possibly less. I cannot imagine trying to frame a history of a religious movement and not acknowledge that, in all likelihood, approximately 94-95\% of the population of the period were not literate, especially given the well-known privileging of the oral episteme in India. It therefore appears a questionable use of the available data to insist that we only consider those representing themselves in the literate record, and not acknowledge how the many others were represented by those few who could actually write.

\section{Cue the Magicians}

This is a somewhat loquacious introduction to the problem of sorcerers, witches and magicians in ancient and medieval India. Certainly, such figures are attested quite early, and their attestation continues on to the present. Yet they do not represent specific sectarian traditions associated with tantrism, even if the behaviors are similar to or overlap with them to a degree. In this regard, we may observe that there is a difference between the social life of the individual, the professional behavior of persons allied to groups or not, and the identity of the person as a member of a specific group. At the advent of an investigation, it is useful not to conflate these.

I am quite aware of the problems of definition associated with sorcerers, witches and the like. Virtually all who have written on this issue have commented on the fuzzy category structures involved (e.g., (Goudriaan 1978, pp. 1-2, 58-59; Kapferer 1997, pp. 8-12)), but most such discussions emphasize the categories of sorcery or magic as an ideology or behavior rather than sorcerers as a social form; they emphasize witchcraft rather than witches. Moreover, Indian literature is not impoverished in their cataloging of these behaviors. The Brahmajālasutta in the Dīghanikāya, for example, mentions 115 different skills—-from reading of signs to mirror divination — that might qualify as sorcery or witchcraft (Dīghanikāya I.9.1-11.22; Sumañgalavilāsinī I.92.9-97.19). Because we can expect that many such behaviors would have been aggregated in a single individual, we do not know from such lists how they were associated or how the aggregation would have occurred: Is prognostication via visions visited on boys and girls handled by the same individual? What about reading signs from mice or the attributes of elephants - were they related? Does one both raise vetālas and speak with yakșas or are these different specialities? These are not inconsequential questions, as we shall see.

In contrast, our problem is simultaneously simpler and more complex, as we are first and foremost concerned with the activities of social, lineal, clan or caste groups operating under selective indigenous identity designations: yātudhāna, ikșanikāa, māyākāra, aindrajālika, vidyādhara and so on. They should be differentiated, as much as possible, from the saints that acquire magical powers-siddhi or $r d d h i$ - through religious actions, such as via ascetical tapas or by meditative practices like dhyanna. That is, there is a difference in kind between claims about a saint attaining psychic powers through 
meditative success or spiritual purity and claims about powers that are transmitted through groups from one individual to another, often from the communication of spells or the performance of a ritual. Even then, the distinction blurs when we see spells obtained by tapas, meditation or other kinds of virtue. However, I would at the same time argue that there is a difference in sensibility between magical power that cannot be shared-as religious ability—in distinction to a spell that can be accidentally overheard or ceremonially transferred from one to another with no loss of efficacy. We are expected to understand that siddhi or the psychic powers of abhijiñ $\bar{a}$ cannot be accrued by overhearing spells at night, while the sorcerer is muttering in his sleep.

To comprehend the social and ritual world of these liminal figures, we could understand that a single individual plays multiple roles, effecting multiple ritual functions and systems, much as we see from other religious agents of the period. Moreover, we also see figures described in literature without specific titles, so such category structures should be suggestive guides rather than exhaustive and closed systems. In any event, the English language category structure is, for the moment, less compelling than the Sanskrit, Pali and Prakrit category structures. So I propose to look at some of these categories in their context and see what they have to tell us.

\section{Yātudhānas}

The history of the study of magic in India-through the work of Keith, Henry, Goudriaan, and Siegel among others-has only secondarily addressed the social issues with which I am concerned. Türsig and Grafe were the really the first to embrace fully a similar project, and Türsig's classic article on abhicāra identifies magical rituals of death—specifically krtye -as a focal point of the both Angirasas (e.g., AVŚ 8.5.9) and, in particular, the yātudhānas, those enemies of Indra and of the rșis mentioned as early as the Rgveda. The noun yātu in yātudhāna is sometimes identified with the other early term for magic or sorcery, krtyā, although the term yātu appears sometimes to be employed as an abbreviation for the yātudhānas. (AVŚ 8.3.2c: $\bar{a}$ jihvayā mūradevān rabhasva kravyādo vrșțtoāpi dhatsvāsan || 2|| ) Whitney's translation evokes the power of the expression, "Do thou, of iron tusks, O Jātavedas, kindled, touch the sorcerers with thy flame (arcis); take hold of the false-worshipers with thy tongue; cutting off (?) the flesh-eaters, shut them in thy mouth." (Whitney 1905, vol. 1, p. 481). Here the yātudhānas are understood to invoke a specific class of gods, the mūra/mūla-devas, a group that was important at the time, even if its identity and extension are poorly understood today.

Yātudhāna sorcerers certainly were accorded exceptional powers, which perhaps validates the extraordinary fear of them expressed, especially in the RV X.87 and eighth kanda of the Atharvaveda Śaunakìya. Six categories of yātudhāna action are particularly suggestive:

1. They are there identified as descending in the air-RV 10.87.6: yad vāntarikșe pathibhih patantam; AVŚ 8.3.5c: anarikṣe patantam yātudhānam. We might also note the mention in Atharvaveda Śaunakīya 4.20.9 that describes the things that fly in the sky, contiguous to asking to see yātudhānas and the demonic piśācas.

2. They seize with spears things obtained or acquired. (AVŚ 8.3.7: ālabdhānnām ṛștibhir yātudhānān).

3. They conduct "root" magic associated with the "root-gods" (mūradevāh) who the Vedic rṣis believe ought to be destroyed (AVŚ 8.3.10, 8.4.24, 4.28.6: śrnehehi tredhā mūlam yātudhānasya; AVŚ_4,28.6a: yah krtyākrn mūlakrd yātudhāna). It may be seen that Mānavadharmaśāstra 9.290 declares fines against anyone invoking the mūlakarmāni rites and pronounces that the performance of such rituals constitutes a cause for the loss of caste (Mānavadharmaśāstra 11.64), suggesting the perdurance of this class of malignant ritual (Bloomfield 1913; Sen 1968).

4. They steal with speech (AVŚ 8.3.14: vācā stenam).

5. They smear themselves with the flesh of humans, horses and cattle (AVŚ 8.3.15: yah pauruṣeyena kraviṣā samañkte yo aśvyena paśunā yātudhānah I). 
6. They employ sorcery associated with small animals and birds-owls, owlets, dogs, cuckoos, eagles and vultures (AVŚ 8.4.22: ulūkayātum śuśulūkayātum jahi śvayātum uta kokayātum I suparnayātum uta gṛdhrayātum dṛ̣adeva pra mrṇa rakṣa indra II).

Atharvaveda Śaunakīya 2.24, lists eight types of yātudhānas, or yātus, and I provide the list here: śerabhaka, śevrdhaka, mroka, sarpa, jūrni, upabde, arjuni, bharūji. These are somehow all types of Kimīdins, apparently another kind of sorcerer about which little is known. So far as I am able to tell, many of these eight designations have eluded successful linguistic analysis. The uncertain nature of these words leads me to wonder whether they might be proper familial or place names rather than a non-clan based typology as understood by others (cf. AVŚ I.28.1-4, I.7.1). In Sāyana's commentary he treats these as personal names but apparently operating within a group following the leader, with whom I would presume the group members had some consanguine relation. Since both brahmans and sorcerers are otherwise known to establish themselves in familial lineages, we may presume that yātudhānas did as well, and by the time of the Vāyupurāna (II.5.114, II.8.123), they were mythologized as snakes, rākșasa demons and descendants of Kāśyapa. Yet they were notably also described as following the cult of the sun, wandering with the solar deity, thus placing them in association somehow with the two primary priesthoods of the solar cult, the Magas and the Bhojakas (Bronkhorst 2014-2015); even then, the parameters of this statement remain unclear as it relies on the broad strokes of the Vāyupurāna.

The sense that we are speaking of familial magical cultures is buttressed by intermittent references to females of the species, the yātudhān $\bar{\imath}$ who are also mentioned both in the Atharvaveda and thereafter. Beseeching Indra, the 1000-eyed god,

darśaya mā yātudhānān darśaya yātudhānyaḥ I piśācānt sarvān darśayeti tvā rabha oṣadhe | | 6 | | AVŚ 4.20.6

Show me the sorcerers; show the sorceresses; show all the piśäcas; with this intent I take hold of thee, O herb. (Whitney 1905, vol. 1, p. 185, trans.)

As late as the Bhāgavatapurāna, the female yātudhān $\bar{\imath}$ were described as in the retinue of the Asura Hiranyākș̣a, "O sinless one, the mountains appeared with yātudhāniss observed residing in the directions, releasing weapons, having spears and wearing their hair loose" (Bhāgavatapurāna 3.19.20 girayah pratyadrśsyanta nānāyudhamuco 'nagha I digvāsaso yātudhānyah śūlinyo muktamūrdhajāh I I).

As with the yātudhānas' relations to most of the Vedic divinities, Indra is their primary antagonist, with other gods like Soma, Agni, Mitra-Varuna, and Rudra (AVŚ 6.32.1-3) also charged to defeat them. However, in one hymn, AVŚ 6.13, they are paid homage as incorporated with death, and at the same time they are loosely associated with medicine, and with mūla magic.

namas te yātudhānebhyo namas te bheșajebhyah | namas te mṛtyo mūlebhyo brāhmaṇebhya idam namạ̣ | | AVŚ_6,13.3 | |

Homage to thy sorcerers; homage to thy remedies; homage to thy roots, $\mathrm{O}$ death; this homage to the brāhmans. (Whitney 1905, vol. 1, p. 290, trans.)

The specter of the yātudhānas was sufficiently dreaded that Rgveda 7.104.12-16 relates a hymn, interpreted to reflect the contest of Vasiștha with Viśvāmitra. Vasiștha, having had his hundred sons destroyed, is accused of being a yātudhāna, which he vehemently denies in an oath, cited in some Dharmaśāstras as a method for proof (e.g., Mānavadharmaśāstra 8.110; Nāradasmṛti I.221). A similar accusation was made in the Vālmīki Rāmāyana that Yadu was demonic and his progeny were rākșasas and yātudhānas (Rāmāyana 7.59.14-20), part of a larger sphere of association between demons of various varieties and the sorcerers. In addition, the specter of conflict seems to shadow the demon-sorcerer relationship—the Anuśāsana-parvan of the Mahābhārata 13.3.4 portrays Viśvāmitra issuing forth countless yātudhāna sorcerers and rākṣasas because of his arrogance at destroying the hundred sons of Vasiștha. 
Despite these and related episodes, we may still acknowledge that the magical system of the yātudhāna remains something of an empty set. ${ }^{9}$ The depiction of Viśvāmitra in the Anuśāsana-parvan is already hybrid. He creates a rākșasi demoness out of the homa fire, signifying the brahmanical ritual component, yet the rāksṣasi's name was yātudhāni and was the scourge of his enemies, the seven $r \underline{r i s}$. Ultimately, however, the rṣis defeat the yātudhān $\bar{\imath} r \bar{a} k s ̣ \bar{a} s \bar{i}$ in a riddle contest. So, other than their use of malignant magic, stealing with speech, very close association with rākșasas, piśācas, mūradevas, animal spirits, and occasional dabbling in medicine, the early texts tell us less than we would wish about the yātudhāna group identity and ritual systems.

Factors like these lead me to believe that the designation yātudhāna operates rather as a cypher for the non-brahmanical magical threat, a brahmanical category for magicians understood to have a social and ideological location distinct from brahmanical authority and the Vedic mantra corpus. Thus, the designation yātudhāna in ancient and medieval India invokes nomenclature presumably referencing individuals or groups, but it is unlikely to specify the name that they would have employed for themselves as a self-identification. Part of the evidence for this is the simple observation that the designation yātudhāna appears nowhere in the Pali Canon. Nor does it, so far as I have been able to discover, occur in any surviving Buddhist Sanskrit records, although the Mañjuśriyamūlakalpa includes yātu as a kind of magic associated with disease (Mañjuśriyamūlakalpa 21.19ab narā yātuvyādhibhir hanyate tadā). Searches for a Prakrit or Apabhramśa equivalent to the term yātudhāna have equally been unsuccessful. Yet the term continues to surface in brahmanical literature like the grhyasütras, largely because their invocation of the Vedic texts as authoritative voices, and yātu survives in modern Indic languages in its cognate $j \bar{a} d \bar{u}$ as a term for both magic and magicians (jādugar: (Glucklich 2012)).

\section{Ikṣaṇika/Ikṣaṇikā, Their Yakṣas and Vetālas}

In distinction, the other terms I hope to explore appear non-denominational, for we find variations on them in a variety of contexts, both secular and religious. For example, in part of its discussion of the means for conquering other states and creating sedition in them, the Arthaśāstra recommends that several classes of individuals should be employed as the fake news of the period-by propagandistically broadcasting the 'king's powers' that he had displayed in a previous deceptive show of omniscience or by his agents deceptively playing the part of gods appearing in fire halls, only to announce the authority of the king.

\section{tad asya svavișaye kārtāntikanaimittikamauhūrtikapaurānikekṣaṇikagüḍapuruṣāh sācioyakarās taddarśinaś ca prakāśayeyuh | | Arthaśāstra 13.1.7}

And secret agents acting as fortunetellers, interpreters of omens, astrologers, fabulists, seers, and those imperial assistants who have witnessed [the ruler's deceptive displays], they should all broadcast these legends in his own territory.

While the difference between some of the terms-especially the kinds of fortune tellers (kārtāntika, naimittika)—is not entirely clear, the person of the ikṣanika or, alternatively, ikṣanika would seem to indicate a seer, one who finds or sees objects or events distant in time and space.

Often we are informed they have assistance, and there is an old Jaina allusion to the similarity of sounds heard following the demise of a Jina to a secret request made by a female $i k s ̦ a n i k \bar{a}$. The early verse supplement to the Āvaśyakaniryukti, the Mūlabhāsya, ties a plethora of skills to the mythic lives of the Jinas. Upon the Jina's demise we are told in the Mülabhāsya that the following extraordinary sounds are heard:

\section{chelāvanam ukkiț̣hāi bālakîlāvanạ̣ va seṃțāï |}

9 In this they are similar to the Angirasas, who were said to have had an Ángirasakalpa, containing their dark rituals. The contemporary texts under that name, however, appear later and invested with much tantric lore; see (Sanderson 2007) for the Oriya versions. 
iṃkhiniāï ruam vā pucchā puṇa kị̣ kahaṃ kajjaṃ | | 28

[Then may be heard sounds of] a burst of laughter out of joy, the playing of children or a lion's roar; or the sounds from a Seeress and so on-the question having been asked, then the reply [specifies] what is to be done and how.

ahava nimittāinam suhasaïäï suhadukkhapucchā vā I iccevamāï pāeṇuppannam usabhakālaṃmi | | 29

Or there will be questions about signs, etc., or [dreams] while resting peacefully—these inquiries will be made about future pleasure or distress.

Thus, all these arose at the moment of death during R̦sabha's life.

In Jñānasāgara's 1383 CE Âvaśyakaniryukty-avacūrṇi, commenting on these Mūlabhāṣya couplets, indicates that the $i k s ̣ a n i k \bar{a}^{\prime}$ s questions are posed in secret:

pracchannam prcchā sā inkhanikādirutalakṣaṇa inkhanikā hi karnamūle ghanṭikām cālayanti tato yakṣāh khalv āgatya tāsām karṇneṣu kimapi praștur vivikșitam kathayanti । (Āvaśyakaniryukty-avacūrni 1.215 to Mūlabhāṣya 28 on Āvaśyakaniryukti 2.207) ${ }^{10}$

That question [to the seeress or to the yakșa] is posed covertly, being characteristic of the sounds of the seeresses, etc. Actually, seeresses shake a little bell at the base of their ears, and then yakșas come and somehow express the answer desired by the questioners into the ears of the seeresses.

The image is delightful - a small bell is rung next to the seeress's ear, and this apparently requires the yaksa familiars to come and answer questions. The sound of the bell is tantamount to the voice of the yaksas, who are otherwise invisible. Thus, the whisperings of the seeress's questions, and probably the covert and invisible yakșa answers, are analogous to the soto voce of various sounds miraculously occurring upon the demise of the Jinas. ${ }^{11}$ A verse in the Brhatkalpabhāsya (v. 1312) again describes the ikṣanikā in this way; Kṣemakīrti's 13th century continuation of Malayagiri's 12th century commentary adds that the yakșa is her kuladevatā, her family deity, and that the ikṣanika is an outcaste dombi. ${ }^{12}$

We may believe that the ikṣanikas were similar to the naimittikas, those soothsayers who made a living by reading signs of various kinds and who are a bit outside of the parameters of this essay. ${ }^{13}$ And it is true that these are sometimes grouped together, yet the range of behavior attributed to these ikșanikas is greater than finding lost items or answering obscure questions, as seen elsewhere in Buddhist literature, whether in the Sanskrit or Pali form. Perhaps our most dramatic portrayal

10 Despite its relatively early date, it can not be said that the Ávaśyakaniryukti and related literature has received the attention that it is due, possibly because of the difficulty of handling the Prakrit materials. See (Leumann 2010; Balbir and Oberlies 1993; Bruhn 1998).

11 I would wonder if this practice is not the actual source of the yakșa well known through Jaina and epigraphic sources, Ghantakarna, generally interpreted as the yakșa with "bell-ears"; see (Cort 1997, 2000) on this figure. One problem for the idea that name may be based on a ritual is that we find, for example, the Tala image, a curious and highly disputed statue, where his testicles are carved in the image of bells; see (Nigam 2000) for disparate opinions on the nature of this image. It suggests the possibility of an iconography in which the yakșa's ears were actually understood as bells. The other problem with the ritual being the source is chronological: I have found no early, authentically pre-epigraphical source describing this ritual in that manner; see the following note.

12 Bṛhatkalpabhāṣya 1312:pasiṇāpasiṇaṃ sumiṇe vijjāsiț̣haṃ kahei annassa I ahavā āiṃhiṇiyā ghaṃṭiyasiț̣haṃ parikahei | | Bhrhatkalpabhāṣya-ṿ̛tti: yat svapne 'vatīrnayā vidyayā vidyāọhiṣthātryā devatayā śiștam kathitam sad 'anyasmai'

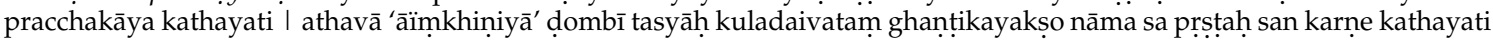
I sā ca tena śiștam kathitam sad anyasmai prcchakāya śubhāśubhādi yat parikathayati eșa praśnapraśnaḥ | | On the summary history of the textual exegesis, Bṛhatkalpabhāsya, Bollée vol. 1, pp. 1-5.

13 This is perhaps drawing a line in the sand, as nemittika/naimittika are sometimes lumped with those who perform ritual enterprises; Dīghanikâya 1.8.30. However, I have yet to find a ritual system associated with the naimittika, and since prognostication of various varieties is so widely distributed, it appears to fall minimally on the margins of this paper. For references to the naimittika in several sutras, see Edgerton, Buddhist Hybrid Sanskrit Dictionary, sv. The Bhrhatkalpabhāsya and Bhrhatkalpabhāṣya-vṛtti 1313 discuss the term nimittājīva as one making a living revealing information about the past, present and future, which seems to describe the revelation of knowledge rather than the exercise of prophylactic rituals. 
of an iksanikā is in a section of the Saniyuttanikāya, the Mangulitthisutta, where she is depicted in the fourteenth in a series of formulaic statements on the consequences of unwholesome action:

idhāhaṃ āvuso, gijjhakūțā pabbatā orohanto addasaṃ itthị̣ duggandhị̣ man்gulị̣ vehāsaṃ gacchantim I Tam enam gijjhāpi dharikāpi kulalāpi anupatitvā anupatitvā vitacchenti, vibhajenti I Sā sudam ațtassaram karoti I Tassa mayham àvuso, etad ahosi I acchariyam vata bho, abbhutam vata bho I evarūpo' pi nāma satto bhavissati evarūpo' pi nāma yakkho bhavissati evarūpo'pi nāma attabhāvapatilīanho bhavissatī'ti I ... Esā bhikkhave itthi imasmiñã eva rājagahe ikkhanikā ahosi I Sañyuttanikāya II.260

Friend, now I was descending from Vulture Peak and saw a woman, foul smelling, of jaundiced complexion, traveling through the air, while vultures, crows ${ }^{14}$ and falcons were following her, pecking at her and driving her away. For her part, she was screaming. So it occurred to me, friends, that this is really strange, quite extraordinary, that there would be a person of this kind, or perhaps there would be a yakșa of this variety, one who would be in this particular embodiment. (then follows a discussion of the karmic causes for her affliction) I understood, O monks, that I had seen the seeress of Rājagrha.

In the Samyuktägama (T.99.2.137a16-b3) in Chinese we find the equivalent text, but there distributed by gender, describing both the seer and seeress of Rajjagṛha, with curious gender-specific additions: she has an iron pestle on her head (頂有鐵磨śirasi muśalam abhavat?) glowing with fire and revolving; he travels as if in a whirlwind. They both delude beings by trying to find valuable things for them. There is much of interest in this description, but we should be wary, as it is strikingly formulaic, both in language and in textual placement. In it, for example, we see echoes of the Atharvaveda image of the yātudhānas descending through the intermediate space. Yet also, in both the Sanyuttanikāya and the Samyuktāgama, virtually the same description is also applied to a variety of spirits: preta, yakșa, etc., so that it is by no means unique to the seers/seeresses. However, both the scripture and the commentary (Sāratthappakāsinī II.221) reinforce the consistently close association of these figures and their spirit familiars, as the same discourse structure can be applied by the Buddhists to both.

Still, there remains the visionary ability of assisting others to find lost things or foretelling the future. This specific attribute is in accord with the description of a practice found among the group of six bhikṣun̄is in the Dharmaguptavinaya, translated by Buddhayaśas and Zhu Fonian between 410-412 CE.

Dharmaguptaka-vinaya-vibhanga T. 1428.22.774c21-775a3

爾時婆伽婆。在舍國祇樹給孤獨園。時六群比丘尼。學習術以自活命。

術者。或支節利。或起尸鬼。或學知死相知轉禽獸論。

卜知鳥音聲。諸比丘尼聞。中有少欲知足行頭陀樂學戒知慚愧者。

嫌責六群比丘尼言。汝等云何。乃學習如是諸術。乃至知鳥音聲。

即白諸比丘。諸比丘往白世尊。

The lord was staying in Jetavana, at Anāthapiṇụadārāma in Śrāvastī. Then the group of six bhikṣuniss studied mantras to earn a living. The mantras were those of prognostication through signs (aingavidy $\bar{a})$, concerning warfare (kșatravidy $\bar{a})$, raising the dead, knowing the signs of death, or the teaching on transformation by [rituals involving] small animals and birds, and prognostication using bird calls. All the bhikșuniss heard [about them], and among them was one with few needs and content ( ${ }^{*}$ alpeccha samtusțta), practiced in the dhütagunas, who enjoyed studying the Vinaya, and knew modesty and decorum. Angrily she scolded the six bhikșunīs, "What do you say about your actions, that you have studied

14 Sanyutta II.260.4 reads dharikāpi, but dharika is unattested; the refrain from the first section II.255.13 has kākāpi instead, and I have translated that. 
these mantras, up to prognostication by bird calls?" She spoke to all the monks, who went to the Buddha.

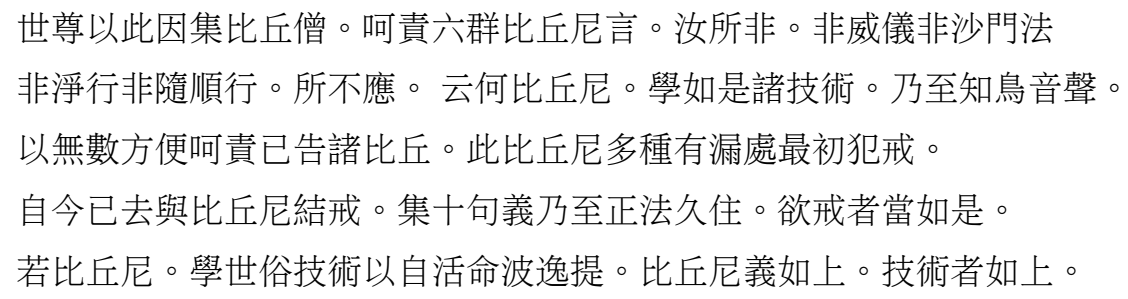

The Lord for this reason called together the bhikṣu samgha, and scolded the six bhikșunīs saying, "These are that which you should not do-this is not proper deportment, not the śramanadharma, not brahmacary $\bar{a}$, not following that which is to be done. They are not to be accomplished! What do you say, bhikșuniss, that you studied these techniques, on up to prognostication by bird calls?"15

Of course, the nuns agreed that they had studied these practices. And, despite their occurring in specifically Buddhist texts, it is certain that these are not Buddhist practices, for they would not have been so reprimanded. Indeed, some of them-like angavidy $\bar{a}$ and kșatravidy $\bar{a}$-seem straight out of the list detailed in the Brahmajālasutta, and find resonance in Jain scriptures as well. ${ }^{16}$ Rituals using small animals and birds had already mentioned in conjunction with the yātudhānas and will be examined in later contexts. As in our other instances I wish to consider, there is also no sign that this was associated with any specifically sectarian enterprise at the time, and none of the designations associated with these mantras seem dedicated to a single divinity. At most, they drift toward the broad Smārta-based vidhāna or pariśișta rituals, and the conclusion of this episode in the same Vinaya indicates that if you read laukika texts for the purpose of healing or mitigating problems, then there is no difficulty (Dharmagupta-vinaya-vibhanga T. 1428.22.775a11-13). Both the Buddhist and Jain problem with such practices is the issue of right livelihood more than anything else-employing mantras for profit.

We note that the mantras mentioned are wider than simply understanding the prognostication from signs, and include the mantras controlling the dead, implicating vetāla rites. The lore on the raising of the dead and conquering the creature has been described in various Buddhist Vinayas, most expressly the Sarvāstivāda and Mūlasarvāstivāda Vinayas, and the agents are also represented as wayward Buddhist monks or nuns (Huang 2009; Skilling 2007).

In the Bhaisajyaguru-sūtra, the vetāla rites are equally associated with rituals dedicated to the yakṣas and rākșasas:

\section{Gilgit Manuscripts I.13-14; T.449.14.402c7-113 trans. Dharmagupta 616 CE.}

To. 504, fol. 278a4-b1: punar aparam mañjuśrịh santi sattvā ye paiśunyābhiratāh sattvānām parasparam kalahavigrahavivādān kārāpayanti I te parasparam vigrahacittāh sattvā nānāvidham akuśalam abhisamskurvanti kāyena vācā manasā anyonyam ahitakāmā nityam parasparam anarthāya parākrāmanti I te ca vanadevatām āvāhayanti ṿ̛kșadevatām giridevatām ca śmaśāneșu pṛthak pṛthag bhūtān āvāhayanti tiryagyonigatāṃś ca prānino jī̄itād vyavaropayanti māmsarudhirabhakṣān yakșarākșasān pūjayanti I tasya śatror nāma vā śarīrapratimām vīā

15 Cf. also Dharmaguptaka-vinaya-vibhangga 1428.22.754a17-b10, under pāyantika \#117 and restated 745b11 in pāyantika \#118. It is possible that the six bhikṣun̄is described in the Dharmaguptaka-vinaya-vibhanga were understood to be naimittikās, thus defeating my category restriction, but I have seen no verification of this.

16 Anggavijjā is no. 16 and khattavijjā no. 18 in the list of micchājī̃a in Brahmajalasutta at Dighanikāya I.9.7; Sumañgalavilāsin̄ 1.93.10-18. I assume the Chinese translation as if ksatriya (利) really references ksatra instead. A similar warning on livelihood is found in Uttarädhyayana 20.45: je lakkhaṇạ̣ suvina paümjamāne nimittakoūhalasampagāḍhe । kuhedavijjāsavadārajīin̄ na gacchaī saranam tammi kale | | 'One who practices a life of deceptive spells, employing himself by [interpretation of] dreams and qualities, devoted to fraudlent statements concerning signs, will be without refuge when karma come due.' 


\section{kṛtvā tatra ghoravidyām sādhayanti kākhordavetālānuprayogena jīvitān antarāyam śarīravināśam vā kartukāmāh $\mid$}

Moreover, Mañjuśrī, there are beings who are addicted to slander and cause mutual strife, fighting and discord among beings. They are beings with minds intent on mutual belligerence and perform unwholesome acts. By means of body, speech and mind they desire injury to each other and are intent on each other's misfortune. They invoke a forest god, or a tree or mountain god, or invoke spirits in individual cremation grounds. They deprive beings born into the womb of animals of their lives and offer yakșas and rākșasas food of flesh and blood. Having made an image of the body of an enemy, they accomplish terrible spells, or desire to damage beings or the destruction of [beings'] bodies by the practices of kākhordas and vetālas.

Here we find the distinctive affirmation that, first, there are cultic associations with specific local divinities and, second, as in the case of the bhikșunīs we find the aggregation of practices associated with apparently several different groups, appropriated on an as-need basis.

Indeed, various narratives suggest that few ritual practices were tradition specific: A spell with a distinct vetāla function-raising a corpse from the dead (matakuțthāpanamanta)—is identified in the Sañjīvajätaka (Jätaka I.510, no. 150), said to have been learned by the bodhisattva while residing in Taksaśilā. The idea of corpse revival to speak truth in response to a question is found in the story of the ascetic Korakkhattiya in the Dighanikāya, indicating that the early Buddhists were familiar with the idea if not themselves practicing the ritual (Dīghanikāya III.8).

However, a specifically $i k s ̣ n i k \bar{a}$ association with a vetāla-like practice occurs in an interesting episode described by the Asilakkhanajātaka (no. 126) and demonstrates that these seers/seeresses were also expected to engage in charnel ground rituals. In the Jātaka story, a prince seeks to take his beloved princess away from her father, the king, who does not approve of the union. The princess is pining for her love in the melodramatic manner found in Indian amorous literature. The prince asks an ikșanika to assist him in spiriting the young lady away. She agrees and reveals how it will be accomplished.

ahạ̣ rājānam upasamkamitvā evam vakkhāmi: 'deva rājadhītāya upari kālakaṇn̄a atthi, ettakam kālam nivattituā olokento pi n'atthi, aham rājadhītaram asukadivase nāma ratham āropetvā bahū āvudhahatthe purise ādāya mahantena parivārena susānamgantvā mandalapițthikāya hețțhāmañce matamanussam nipajjāpetvā uparimañce rājadhïtaram țhapetvā gandhodakaghațānam ațthuttarasatena nahāpetvā kālakaṇnim pavāhessāmm' ti Jātaka I.456.14-20.

I'll approach the king and propose to him this idea, "Lord (I'll say), the princess has a Black-eared spirit (kālakannin) hovering over her. You shouldn't even for a short time think about warding it off. Here's what I'll do-on a specific day, I'll take the princess, we'll get on a cart, and surrounded by many men carrying their weapons, we'll head to the cremation ground. There, below a bed set up on top of a mandala (mandalapițthikāya), I'll place a corpse. On top of the bed, I'll set the princess, and bathe her with the water of 108 jugs of fragrant water. In that way, I'll expel the Black-eared spirit."

Instead of a corpse, though, the seeress will hide the prince beneath the bed, ready to take the princess away. We are informed that the plan unfolds as desired, the king agrees, and the Great Seeress

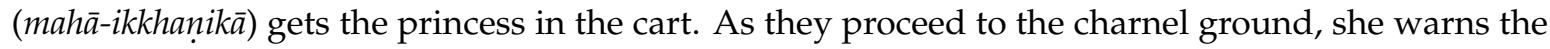
guards to be on their toes,

'mayā rājadhītāya mañce thapitakāle hețțāmañce matapuriso

khipissati khipitvā va hețthāmañcā nikkhamitvā yam pațamaṃ passissati tam eva gahessati, appamattā bhaveyyāthā' ti Jātaka I.457.8-11.

When I've set the princess down on the bed, that corpse underneath will sneeze, and then he'll come out from under the bed. Then, he'll try to grab the first person he sees-so look sharp! 
The prince under the bed has been equipped with black pepper and he puts it up his nose, with the expected results-the gang of guards throw down their weapons when they hear the sneeze, the prince takes his love away to be married, and the king shrugs the whole episode off with a philosophical detachment worthy of the Stoics. For our purposes, however, it is evident that such liminal figures as this $i k k h a n i k \bar{a}$ were invested in all kinds of witchcraft procedures. In addition, while the word vetāla is not employed in the text (much as we saw with the bhikșunīs above), the narrative requires that procedures for corpse reanimation were known to the audience in some manner. Jain and some magical literature similarly describe the animation of a corpse for various purposes without the vetāla designation, so this use appears distributed in various ways across traditions. ${ }^{17}$

At a slightly later date-but approximately contemporaneous to the Bhaisajyaguru description above-and in an analogous vein, the Bṛhatsamhitā of Varāhamihira will describe a maṇalaka figure, attendant on a specific kind of king. ${ }^{18}$

maṇdalakakṣaṇamato rucakānucaro 'bhicāravit kuśalah I

kṛtyāvetālādiṣu karmasu vidyāsu cānuratặ | | 68.37

ṿ̛ddhākārah kharaparuṣamūrdhajaś ca śatrunāśane kuśalah ।

dvijadevayajñayogaprasaktadhīh strījito matimān || 68.38

The mandalaka is an opportunist, in the entourage of a rucaka king, skilled in killing magic (abhicāra), and fond of spells relating to the rituals of the krtyā and vetāla spirits.

He looks old, hair rough and stiff, but skilled in the destruction of enemies. Intellectually attached to brahmans, gods, sacrifice and yoga, he is intelligent, but conquered by women.

As indicated in the verse, this unprepossing character is in the entourage of a specific kind of king, one who is himself not of the highest order, governed as he is by the planet Mars.

subhrūkeśo raktaśyāmah kambugrī̃oo vyādīrghāsyah I

śūrah krūrah śreștho mantrī caurasvāmī vyāyāmē ca | | 68.27

Attractive hair and eyebrows, [the Rucaka king] has a dark red visage, his neck marked with three lines, face very long in shape.

He is a warrior, cruel, a chieftain with secret counsel, the head of a band of thieves, and hard-charging.

Therefore, much as we saw the strong relationship between kings and magicians above, Varāhamihira articulated the idea that there was a class of magicians who were associated with the needs of unsavory rulers, ones who themselves easily crossed the line between legitimate warfare (according to the dharmasütra understanding) and the naked exercise of power for personal gain. The aura of vetālas and krtyās (here interpreted as the raising of a female evil spirit) gave the magician both his power and his liminal status as a member of the thief-king's court.

Moreover, perhaps a word of prudence is advisable concerning attempts at a systematic survey of vetāla rites. My presentation does not even begin to touch on the manifold citations and descriptions of the vetāla or half-vetāla or corpse reanimation rites found in the Buddhist documents in Chinese and Tibetan, very few even identified and fewer critically evaluated. ${ }^{19}$ In aggregate, such evidence would suggest that vetāla rites were recognized as equipment of various kinds of magicians, seers

17 Bṛhatkalpabhāṣya 5540-46 and Dattātreya 11.25 are examples.

18 These verses were noted by Dezső (2010, pp. 398-99), for other purposes.

19 Huang (2009) and Skilling (2007) have explored some of the rich materials available in the Vinayas, but they have only scratched the surface, as this episode indicates. Dezső (2010) explores two types of vetālasādhana, one raising the deceased and the other based on a homa, but seems not to see that the employment of the homa fire rite must be an overlay or a hybrid system, compounded with the indigenous rite of corpse animation. 
and sorcerers prior to the Gupta period and continued to exist down to the present as an optional ritual behavior widely distributed through Indian traditions outside of textual lineages or sectarian affiliation. Attempts to identify early statements of these practices as necessarily associated with the later sectarian tantric lineages should be treated with much caution.

\section{All in the Family: Dākas, Dākinīs, Vidyādharas and Vidyādarīs}

The evidence available suggests that one facet of the role of magician or sorcerer entails familial relations, so that in a very familiar South Asian manner, there seems to have a hereditary component observable in some instances-families of sorcerers, handing the spells down over the generations. An example of this is in the story of miraculous powers (iddhānubhāva) possessed by all the members of the family of a layman called Mendaka, living in the town of Bhaddiya-nagara, related in Mahāvagga section of the Theravada-vinaya (Vinaya I.240). The father could fill his granary with showers of grain; his wife had an inexhaustible pot; his son an inexhaustible bag of money; his daughter in law an inexhaustible basket; even the slave had the magical power to plow a field and leave seven furrows for each one plowed. The many, later versions in Buddhist literature (Ch'en 1953) tie these powers into a story of previous merit (purvayoga) accrued by members of the family, generally by feeding a pratyekabuddha in a time of famine. However, the Mahāvagga makes no such allusions, and its commentary (Samantapāssādikā 5.1101) is silent on a karmic Buddhist rationalization of a family of magicians. It appears that, being a Buddhist partisan, the family was branded with the language of spiritual powers, so that claims about their magical assets were placed in a Buddhist moral cosmos, with the subsequent creation of a prior life of merit to validate the magical attributions as generated by virtue and not from some other source.

That was not the case for those not being part of the Buddhist patronage system, who were given less than honorable designations, merited or not. In addition, the extraordinary abilities attributed to them consequently placed these persons in a liminal sphere, on the social margins where figures of power are considered to have divine/demonic extensions. This is a familiar trope in Indian literature, how one or another category of magical beings-vidyādharas, diakinīs, yakșinīs, etc.—will have both a human and non-human community, and were able to pass seamlessly between the two forms. In each dimension, they were often considered to have familial or geographical associations, especially notable in the female of the species. The earliest female magical persona, as we saw, was the case of the yātudhāniss, the females occasionally identified along with their male counterparts, but other designations were employed at a later date, ones that invoked narratives of familial descent.

Most Indologists are aware of the Gangādhār inscription, that provides the earliest epigraphic evidence for the term dẹkinī, and Bruce Sullivan's discussion of this inscription treats it judiciously (Sullivan 2006). Yet other, approximately contemporary, information is available in textual sources, verified as to their date by their translations into Chinese. ${ }^{20}$ The most important is the Lanikāvatārasūtra, translated by Gunabhadra in 443 and again by Bodhiruci in 513, for this text provides a series of morality tales on the eating of meat. So the king Simhasaudāsa lost his kingdom because of his desire for flesh, and Indra experienced misfortune after chasing the pigeon in the Śivi-jātaka. However, it is one description that interests us:

anyeșāṃ ca mahāmate narendrabhūtēnnām satām aśvenāpahṛtānām ațavyām paryatạmānānām siṃhyā saha maithunaṃ gatavatām jī̌itabhayād apatyāni cotpāditavantah siṃhasaṃō̄sānvayāt kalmāsapādaprabhṛtayo nrpaputrāh pūrvajanmamāmssādadoșavāsanatayā manușyendrabhūtā api santo māmșāada abhūvan I ihaiva ca mahāmate janmani saptakuțìrake 'pi grāme

20 Adelheid Herrmann-Pfandt's (Herrmann-Pfandt 1996) article was the first, in my estimation, to treat this section intelligently. Unfortunately, her article has been left out of the scholarly discussion, so I thought to treat the Lankā̃vatāra section again, in part because she does not verify the Chinese translations. 
pracuramāmsalaulyād atiprasangena niṣevamānā mānuṣamāmsāāā ghorā dākā vāa dākinyaśca samjō̄yante I

And other kings, Mahāmati, carried away into the forest by their horse(s), wandered until, out of fear of their lives, had sex with a lioness, and progeny were born. The princes, beginning with Kalmāṣapāda, through the consequence of [their fathers'] cohabitation with the lioness, and because of the offending karmic outflow of eating meat in a previous life, they continued their carnivorous practices even once they had become kings. And thus in this birth, Mahāmati, in the village of Seven Huts (Saptakutīiraka), [these princes] were born residing as ferocious cannibalistic warlocks and witches, because of an excessive attachment and greed for quantities of meat.

As is usual for Mahāyānasūtras, the verse summary-which is in this case older than the prose-restates the issue:

canḍālapukkasakule dombeṣu ca punah punah | | Là̉kāvatāra-sūtra 8.14 | |

ḍākinījātiyonyāśca māmsāâde jāyate kule ।

Again and again, he is born into a carnivorous family, of wombs in the category of witches, in a family of the candālas or pukkasas, or among the dombas.

Here it would seem most specifically, that $\underline{a} \bar{a} k a s$ and $\underline{d} \bar{a} k i n \bar{\imath} s$ were understood to reside in specific villages and were human beings, or at least appear as such. The $513 \mathrm{CE}$ translation of Bodhiruci simply glosses $d \bar{a} k a s$ and $d \bar{a} k i n \bar{\imath} s$ as men and women who end up as rākṣasas. (T. 671.16.563a24-25: 生諸男女盡 羅). Yet it is relatively clear that the author of this short story understands the rebirth of the princes as dākas and dākinīs in this village of Seven Huts, wherever that may have been.

The representation of female spirits in a family-modeled relationship to sorcerers is the subject of the yakșin̄i-sādhana studied by Yamano (2013). Going back at least as early as the Amoghapāśamahākalparāja, the yakșin̄i is controlled by various means, so that the vidyādhara will command her to perform functions, depending on the configuration of their familial relationship: ${ }^{21}$

vidyādhareṇa vaktavyaṃ tṛbhị kāryasādhanāni me kuruṣva iti mātā bhāryā bhagin̄̄ I yadi mātā putravat paripālayati annapānaśayanavastradhanadhānyaih | bhāryā sarvvopakaranam aiśvaryādhipatin dadāti krīdenānuvicarati | yadi bhaginyā sarvvakāmikamanorathāni paripūrayati I sarvvakāryāṇi kariṣyati | sarvvatra dhāvati I punar āgacchati dine dine ābharanavastrā[va]bharaṇālañkārāṇi dadāti I dine dine anyāni divyastriyam ānayati krīậarthe | Amoghapāśamahākalparāja ms. 30a5-7.

Then the vidyādhara is to say, "You are to perform three kinds of actions for me!" These are, like a mother, a wife and a sister. If [the yakșinī] is to be like a mother, then she is to treat the vidyādhara as a son, protecting him with food and drink, bed, clothing, money and grain. If like a wife, she is to render all services to her lord and master, and to follow his lead in sexual play (krīdenānuvicarati). If like a sister, then she is to fulfill all his desires as they occur. She will do everything that is to be done. She will run everywhere for him, and having returned, she will give him every day every variety of ornament and clothing. Each day, she will bring to him other heavenly women for the purpose of sexual play (krīdārthe).

Thus, the relationships between the sorcerer/witch and his/her familiar were in some sense configured through the understanding of Indian family structure, and it would be curious if this family structure were not continued in the sorcerers' physical lives. $^{22}$

21 This is part of a larger section: Amoghapāśamahākalparāja ms. 30a2-b1; To. 686, ma: 54a1-55a1; T. 1092.20.258c13-259b4.

22 Recent studies on the yoginīs seem to suggest a similar phenomenon may have been at play; see (Serbaeva 2013; White 2013). 
These fifth through seventh century descriptions were not exceptionally different from either the $i k s \underline{a n i} \bar{k} \bar{a} s$ mentioned above or the tribal (matainga) witch (vidyādhari) who is at the center of the early story of Ānanda's attempted seduction by the witch's daughter Prakrti, who had fallen hopelessly in love with the Buddhist saint (Śârdūlakarnāovadāna pp. 1-12). Her mother, the vidyādharī, prepares a homa of 108 arka (Calotropis gigantea) flowers and sends a spell that would fall squarely under the later tantric karma of magical attraction (ākarṣaṇa) or control (vaśíkarana). That such magical behaviors might have some familial base is suggested by the Dhanāidaha copper-plate inscription of Kumāragupta I describing a familial lineage (śākh $\bar{a}$ ) of a vidyādhari or from a vidyādhari, one that applies the curious Vedic metaphor of branch (śäkha) to the description. ${ }^{23}$

The old Bṛhatkathā story literature, like the Vasudevahimdi and the Bṛhatkathāślokasamgraha, mentions the hereditary nature of vidyädhara families and their spells. So in one episode, a young vidyādharī named Vegavatī is humiliated by her playmates because she cannot simply fly up the mountain; she replies that she has yet to receive the spells of her family (Bṛatkathāslokasamgraha 14:33: alabdhakulavidyā). Jamkhedkar (1984, pp. 225-33) has combed through the Vasudevahindi stories of vidyādhara sorcerers, and described the way in which the lineage stretching back to mythic descendants of the Jina Rṣabha, descendants named Nami and Vinamī, eventually produced sufficient descendants of their own to populate cities of either eight, sixteen or sixty-four groups (nikāya) of vidyādharas, depending on the description. Accomplishment of the spells entailed various kinds of temporary religious activities: fasting, recitation of the mantra, various painful penances, to name but the most important. However, receipt of the vidya might simply be performed by securing marriage into the family of sorcerers.

\section{The Illusionists: Māyākāra, Aindrajālika}

Different from the seer or seeress in some ways was the illusionist, variously identified as a māyākāra, one who creates illusions, or aindrajālika, one involved with phantasms. Both Buddhist and Jain literature feature interesting vignettes of such figures, who are usually represented as creating trouble for people or encountering the respective founders of the religions under contentious circumstances. One Buddhist scripture, named after the illusionist Bhadra, describes his situation.

yang de'i tshe rgyal po'i khab kyi grong khyer chen po na sgyu ma mkhan bzang po

zhes bya ba bstan bcos la shin tu mkhas pa I gsang sngags la shin tu mkhas pa I

bzo dang rigs pa la mkhas pa | las kyi mthas' byas zin pa | rab tu byed pa byas pa I sgra grags pa I yul ma ga dhā na sgyu ma mkhan nam I sgyu ma mkhan gyi slob ma ji snyed pa de dag gi mchog to grags pa I phul du grags pa zhig gnas te I des yul ma ga dhā ril gyi skye bo'i tshogs thams cad'dun par byas I rmongs par byas I mgo 'khor bar byas nas I ya mtshan gyi chos la bkod de I bden pa mthong ba rnams dang I dad pa dang I chos kyis rjes su 'brang ba rnams dang I dge bsnyen dang I dge bsnyen ma rnams ni ma gtogs so I I des sgyu mas rmongs par byed pa'i rigs pai's stobs bskyed pas rnyed pa dang I bkur sti dang I tshigs su bcad pa'ang lhag par rnyed do I I Bhadramāyākāra ${ }^{24}$

At this time in the city of Rajjagrha lived an illusionist. Skilled in mantras, skilled in the knowledge of crafts ( ${ }^{*}$ silpavidyā), he had completed tasks ( $\left.{ }^{*} k r t a k a r m \bar{a} n t a\right)$, finished presentations and was famous. Among all the illusionists in Magadha, or among all their disciples, he was known as the finest, renowned as eminent. Having delighted, deluded and confused all the groups of people in all of Magadha, he performed wondrous feats.

23 (Bhandarkar et al. 1981, p. 273): K[o]țtiyā gaṇa(ṇā)d vidyādharī[t]o śākhāto datilācā[r]yya-prajñāpit[ā]ye; "commanded by Datilācāyya (=Dattilācārya) of the Kottiya-gaṇa and the Vidyādharī-śākhā." (trans. Bhandarkar).

24 sTog vol. ca (39), fols 74b5-75a2; the corresponding section in the Derge is To. 65, dkon-brtsegs ca, fols. 18b5-19a1; the older Chinese translation is attributed to Dharmarakṣa: the section here is found T. 324.12.31a7-b4. Compare Régmey's 1938 edition and translation, pp. 20-21,58, and his comments on the Dharmarakṣa translation, p. 13. 
Only those who saw the truth and had faith, those following the Dharma-the upassakas and $u p \bar{a} s i k \bar{a} s$-were exempt (from his deception). Yet he received extraordinary wealth, acclaim and verses of praise, all produced by the power of his deceptive spells of illusion.

Here the description is fleshed out: Our person is an illusionist, a tradition in India to this day, and studied in some depth by Siegel (1991) and Shah (1998). Illusionists—whether designated as māyākāra or aindrajālika-have been a metaphor in Buddhist philosophical texts, like the Bodhicaryāvatāra 9.31, describing the idiocy of the illusionist falling in love with a woman conjured by his own illusion. Or the Ayoghara-jātaka, which in the canonical verses (XV.337) points out that the illusionist who is capable of deluding the crowd's vision while on stage, even then cannot obtain release from death.

And it is true that Buddhist literature does not favor such figures generally. The Candraprabhabodhisattvarcaryāvadāna of the Divyāvadāna (pp. 314-28) features the narrative of the magician (indrajālavidhijña) Raudrākṣa, who is a brahman living on the holy mountain Gandhamādana. Raudrākșa conspires to request the head of the king Candraprabha, who was a previous embodiment of Śākyamuni; Raudrākṣa, of course proved to be a previous embodiment of the Buddha's evil cousin, Devadatta. In another Divyāvadāna section, the Prātihāryasūtra, a similar conspiracy is launched in Sākyamuni's own time by the pariorājaka Raktākṣa, also an illusionist. He is charged by the Buddha's ascetical opponents to rally followers and disgrace the Buddha in Śrāvastī, where he is preparing his great miracle (Divyāvadāna, pp. 151-53). With substantial literary flair, the ruse does not work and the Buddha engages in a series of miracles (pp. 155-66), clearly posed to demonstrate his superiority over the false claims to magic from the ascetic teachers of the period.

Other descriptions of such illusionist figures are found, sometimes in Jain literature. One occurs in the sixteenth chapter of the Nāyadhammakahāo, one of the twelve angas of the Śvetāmbara Jain canon (Schubring 1978). Chapter sixteen is devoted to a Jain version of the previous existence and one episode in the life of the Pāndavas, Draupadī and Kṛnna Vāsudeva. Most interesting for our purposes is the figure of Kacchulla Nārada, who precipitates much of the action in this section. Kacchulla Nārada seems to be the Jain appropriation and reformulation of the persona of the old r̦̣̦i Nārada of Vedic fame, and has been mentioned elsewhere in Jain literature as a magician of note (Balbir 1990, p. 54). He is described as an ascetic with both formulaic and distinctive language employed:

kacchullanāarae damsanenam ä̈bhaddae vin̄e aṃto [amto] ${ }^{a}$ ya kalusahiyae majjhattha-uvatthie ya allīnasomapiyadamsaṇe surūve amaïlasagalaparihie kālamiyacamma-uttarāsamgarä̈yavacche $e^{b}$ damdakamandaluhatthe jadāmaüdadittasirae jannovaïyaganettiya-mumjamehalā-vāgaladhare hat thakayakacchabhie piyagaṃdhavve dharanigoyarappahāne saṃvarañavarana-ovayanuppayaṇilesaṇisu ya saṃkāmaṇi-äbhioga- paṇnatti-gamaṇi-thaṃbhīñ̄su ya bahūsu vijjāharīsu vijjāsu vissuyajase iț̣̂he ${ }^{25}$ Nàyādhammakahāo 16.127.

There was Kacchulla Nārada, very good to look at, educated, playful but internally concealing his corrupt intent (kaluṣa), unbiased between factions, displaying friendliness and determined pleasantness, well-built, his clothing stainless, his chest covered with an outer cloak of a black buck skin, staff and water pot in his hand, his head ablaze with a dreadlocked crest, wearing a sacrificial thread, a rosary, grass girdle and bark clothing, holding a lute in his hand (vin̄ạpanni, a name for the ṛ̣i Nārada). He was loved [for his song] like the Gandharvas, avoiding [walking on] the domain of the earth [as he was

25 Schubring (1978, p.58), reproduces this description but does not translate it; he separates some of the lines in a manner inconsistent with the tīka. Dīparatnasāgar's Āgamasuttāni, edition includes Abhayadevasūri's 11th century tịka, which understands a anta to be repeated; p. 221.5: 'vin̄ie aṃto aṃto ya kulusahiyae' antarāntarā duṣțacittaḥ kelīpriyatvād ity arthah. For ${ }^{\mathrm{b}}$ Abhayadevasūri takes vaccha as vakșas, chest, although it could also be read as vatsa, which may also be understood as the chest; the reading vatthe for vacche given in the Dipparatnasāgar edition (p. 220.22) seems in error. Abhayadevasūri provides a verse in his colophon that indicates he completed his commentary on vijayadaśamī, the tenth day of the month of Aśvin, in VS 1120, i.e., 1063, in the town of Aṇahitapātaka: ekādaśasu śateṣv atha vimśatyadhikeṣu vikramasamānām | aṇahitapāṭakanagare vijayadaśamyāṃ ca siddheyam | | 
always flying]. He was understood to be famous for his spells of the vidyādharas: spells of concealment (samvarana), of cloaking (ävarana), descent (avatarana), ascent (utpatana), affixing someone to his seat (śleșaṇa), entering another's body (sankramana), control over another (abhiyoga), making hidden things known (prajñapti), magical flight (gamana), and immobilization (stambhana).

And even though he was praised by Kṛ̣ṇa, Baladeva and the other Yādava princes, his inner nefarious quality (dustacitta) was manifest by his desire for conflict,

\section{kalahajuddhakolāhalappie bhaṃdan̄ābhilās̄̄ bahūsu ya samarasayasamparāesu dạ̣sañarae sammatao kalaham sadakkhinam aṇugavesamāne | Nāyādhammakahāo 16.127}

He loved conflict, war, verbal disputes, addicted to witnessing the many hundreds of clashes of armies, ardently sought out everywhere the conflicts with their remuneration [for his services].

As a consequence, Kacchulla Nārada enticed the ruler of Amarakañkā, Padmanābha by name, to kidnap Draupadī from the Pāṇ̣avas and create warfare between Hastināpura and Amarakańkā. Curiously, for Jain texts, Kacchulla Nārada escaped from this conflict with no specified karmic consequence, even though the sixteenth chapter of the Nāyadhammakahāo is the perhaps the longest in the scripture.

Now this personality profile represents Kacchulla Nārada in the guise of a tāpasa or a ṛ̣i, and reflects the ideology of the Smārta assumption that those in positions of authority are entitled to it, and not necessarily subordinate to other authority. It also again reflects the expectation that kings are to have strong association with a magical siddhatāpasa, as in the Arthaśāstra, which enjoins kings to secure the presence of illusionist ascetics in a kingdom for protective purposes (4.3.44ab: māyāyogavidas tasmād vișaye siddhatāpasāh). The image is in line with the kind of coercive magic often witnessed in texts featuring the vidyādharas, apparently from whom Kacchulla Nārada obtained his spells. In addition, as we know, the designation vidyädhara represents a crossover human/divine kind of sorcerer, given several descriptions in the Jâtakas and Jain literature.

However, it is germane to observe that obtaining spells via tapas or other means, most generally from the vidyādharas, is a theme as far back as the Vālmīki Rāmāyana (Grafe 2001, p. 75, referencing Rāmāyana 1.21.10-19). And long before any evidence for the emergence of tantric rites, we find various mentions of vidyādharas in literature and inscriptions, occasionally transmitting their spells to others, as is seen in the Jain story of Vasudeva's study of spells from an illusionist (indajāliya) vidyādhara (Vasudevahindi 1.195; Jain 1977, p. 338), from whom he obtained the spells Sumbha and Nisumbha, and who are otherwise known as demonic figures in the purānas. Grafe (2001, pp. 339-50), building on the studies of Van Buitenen (1958), Lüders and others, has given this terminology the most extensive study, and has argued that the vidyädharas were initially humans practicing various spell rituals for magical purposes, particularly evident in Theravāda sources. One canonical Jātaka verse seems to validate this perspective:

vijjādharā ghoram adhīyamānā adassanaṃ osadhehi vajanti

na maccurājassa vajantadassanam tam me matī hoti carāmi dhammam I I Jātaka XV.341

Vidyādharas study ferociously, so that they can

move invisibly by means of medicines.

Yet they cannot travel while invisible to the King of Death;

So it occurs to me that I will travel with the Dharma.

This Jātaka verse represents the vidyādharas engaged in techniques of invisibility, which becomes one of the siddhis at a later period, as well as a means for thieves and others of nefarious purposes, and we see that it is among the most important qualities listed for Kacchulla Nārada. The nefarious potential for invisibility spells is already noted in the descriptions of the mânavas, the thieves of the Arthaśāsta, who are noted as having employed them in service of a ruler: 
antardhānamantrena jāgratām ārakșinā̄m madhyena mānavāān atikrāmayeyuh | Arthaśāstra 4.5.4

Let the [secret agents] have the mannava criminals walk right through the wide-awake security personnel by means of the invisibility mantra.

Little wonder that the invisibility spell is an enterprise featured in the thieves' manual, the Sanmukhakalpa §2.

However, it may be noted that our focus strays a bit in this regard. We should understand there to be a distinction between those who employ spells exclusively for the goals of violating the social compact, and those whose employment of spells is for personal support. This latter may entail a drift to behaviors outside of polite society but is not inherent in their goals, which are more frequently opportunistic but not necessarily nefarious. Magicians, I would argue, are represented in the available literature as dedicated to opportunistic gain, even if they are sometimes framed as pathological predators. Nonetheless, it is germane to observe that the roles may be reversed, and the stories about the duplicitous magician or evil ascetic should be one reference point for all those concerning themselves with Indian religion, as White has persuasively argued (White 2009).

\section{8. Śạ̣vara, Indra and Prakrit Sociolinguistic Evidence}

Some at least of the notices concerning such magicians in the classical or medieval period appear to me to be found in Buddhist or Jain literature, as we have already seen. Brahmanical religious literature tends to occlude these figures for reasons that are not entirely clear, although much speculation is possible. Indeed, we will see later that the Mülasarvāstivāda-vinaya provides one answer even if it is probably not the only position possible. In any event, the reality is that some of the earliest descriptions of magicians outside of the Vedas are located in a Prakrit register, and an avadāna in a collection from Gandhāra, dated to the first half of the first century C.E. is of especial interest.

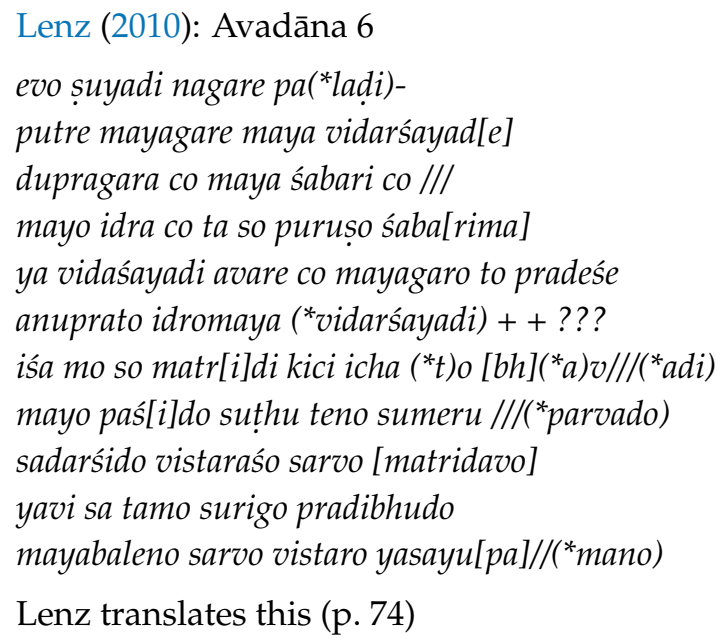

Thus, it was heard. In the city of Pātaliputra, a magician displayed magic. There were two kinds of magic: the magic of Śambara and the magic of Indra. Then, that person displayed the magic of Śambara. And another magician arrived in that place. He (*displayed) the magic of Indra ... He said: "Do you have a desire ("to see a magic display)?" Magic was seen: (*it was) excellent. Mount Sumeru was bought into view by him. In detail, all ("should be said) up to "the darkness overshadowed the sun by the power of magic." The complete expansion should be according to the model.

Lenz notes, both in his discussion of this text (Lenz 2010, pp. 3-14) and analogous ones in the Gāndhārī corpus, that the specialists in the Avadāna literature employed abbreviated notes to preach from, so that the text available to us references a well-known narrative that would probably have been memorized. The notes appear to have been mnemonic devices to prompt the preacher, whose audience would have been familiar with the story, or minimally the types of characters involved. 
Even given its brevity, it is an important early statement about a magical contest in Pātaliputra, where two magicians (G: mayagara Skt: māyākāra) engaged in a test of wits, one employing magic derived from Indra, the king of the gods, and the other invested in magic from Śambara, Indra's nemesis in the Vedas, who was noted with his skill in magic (Parpola 1988, pp. 227, 259-64). Such stories of magical ability versus the ability of the spiritual adepts is not unusual, and frames the Buddhist Prātihāryasūtra in the Divyāvadāna collection as has already been mentioned (Divyā̃adāna, pp. 89-103). And, as in the Gāndhārī story, we may observe that such figures, if they are given a quotation, are sometimes depicted as speaking in a Middle Indic language. This is either because the text is written in such a language, as in the instance of Jain texts in Ardhamāgadhī or Mahārāstrī Prakrit, or in the case of dramatic texts they are provided with that linguistic register as their level of discourse, on a par with women, Buddhists and other second-class citizens.

The Ratnāvalī —one of the three surviving dramas attributed to the Puṣyabhūti emperor Harṣa Vardhana-is a case in point, and provides a later moment in the image of magicians dedicated to Indra and Śamvara. The plot of the drama, and its resolution, requires the activity of an illusionist, an aindrajālika, named Śamvarasiddhi, one who obtains his accomplishment from the god Śamvara. As with other lower caste actors, Samvarasiddhi speaks in the Prakrit of the dramas. He is from Ujjain, and introduces himself to the king by giving a homage to his divinities:

panamaha calaña indrassa indajāla-apinaddhanāmassa ।

taha jjevva saṃbarassa māāpsupariṭhthidajasassa || $4.7^{26}$

We bow down to the feet of Indra, whose identity is bound up into his illusory powers,

And as well to Śamvara, whose fame is established by his phantasm.

King Udayana is intrigued by the magician, and the Queen Vāsavadattā is supportive, as she is also from Ujjain, so Udayana asks the peripatetic magician what illusions he can perform. Śamvvarasiddhi replies,

kị̣ dharan̄e miämko āāse mahiharo jale jalaṇo I

majjhahṇahmi paoso dābijjaï dehi ạnattim I I Ratnāvalī 4.8

Do you wish to see the moon on earth, or a mountain in the sky,

or fire in the water or twilight at noon-whatever you command!

kim jappidena bahuṇā ihasi hiäena jạ̣ jạ̣ devam dațthum I

tạ̣ tạ̣ damsemi aham guruṇo maṃtappasādeña | | Ratnāvalī 4.9

Well, enough of this blathering on. Whatever god you wish in

your heart to see, that god I will show to you, by the grace

of my guru's mantras.

Thus, notwithstanding the agonistic relationship between Indra and Śamvara described in the Vedas that carried over into the Gāndhārī Avadāna, by the time of the Ratnāvalī, their lineages of

26 The manifold discrepencies between the editions of Ratnāvali 4.7-9 appear indicative of the problems of the transmission of Prakrit texts in general. Carpentier p. 361 reads:

paṇamaha calaṇe indassa indaālammi laddhaṇāmassa | taha ajjasambarassa vi

māāsupaditthiäjasassa | | 4.7

kị̣ dharan̄ie miänko āāse mahiharo jale jalaṇo | majjhaṇhammi paoso dāvijjaü dehi ānattị̣ | | 4.8

kiṃ jappieṇa bahuña jam jam hiäeṇa mahasi saṃdaț̣huṃ I tạ̣ tạ̣ dāvemi aham guruno mantappahāveṇa

I| 4.9

Kale (1921, pp. 95-96): panamaha calana indassa indajālaapinaddhanāmassa | taha jjeva sambarassa māāsupariṭhṭhidajasassa | | 4.7

kị̣ dharaṇie miännko āāse mahiharo jale jalaṇo | majjhahṇahmi paoso dābijjaï dehi āṇattiṃ | | 4.8

[ahạ̣ vā kị̣ bahuṇā jappideṇa |] majja païṇ̣ā esāṃ jạ̣ jaṃ hiäeṇa ihasi saṃdaț̣hum I tạ̣ tạ̣ dạ̣semi ahaṃ guruno mantappabhāveña || 4.9

Similar variations are found in Bhattarcharya and Kavyatirth, pp. 342-43, Chakravarti, p. 104 (2nd half). I have, for the most part, followed Kale's text, excepting in 4.9, where I follow Chakravarti. 
magic had come together into a single person. Whether this was because Indra had been moved from the center to the periphery with the rise of the new gods of Hinduism, or for some other reason it is difficult to say.

Yet we note that the protagonist Śamvarasiddhi, both in his homage and his name, indicates his devotion to the magical deity Śamvara, the devatā who will be prominent in the Buddhist yogini tantras a hundred years hence, and that he claims to belong to some kind of lineage, exercising his art by the grace of his guru. As with the māyākāras of the Gāndhārī story, he is an illusionist, and in the Ratnāvali, his activity is required by the plot-he must kindle an illusionary fire so that the members of court believe the domestic apartments to be ablaze and release the imprisoned princess Ratnāvali , for whom the drama is named. In some sense Śamvarasiddhi is a key to a conundrum I could not solve previously (Davidson 2002, p. 214), how Śamvara, the old illusion-related divinity of the Vedas and Brahmanas should end up in the Buddhist canon. Indeed, the evidence from the Gāndhārī Avadāna leading up to the Ratnāvali suggests that a vernacular language based tradition of magical practice thrived around this god, to be appropriated by the Buddhists at a later date.

\section{Caste Again}

One cannot explore such topics without continually bumping into the issue of caste and class-even Śạvvarasiddhi is referred to as the [illegitimate] son of a slave girl in Ratnāvalī (Carpeller p. 362.23: dāsie putta indraāliä)—and we saw that various figures like the $i k s ̦ a n i k \bar{a} s$ have been described in outcaste or lower caste terms. But one episode brings together many of these elements and is, because of its entertaining nature, worthy of relating in extensio. The Mūlasarvāstivāda Sanighabhedavastu, in its narrative of the great schism precipitated by Devadatta, relates how the schismatic monk subsequently lost the psychic power ( $r d d h i)$ that he had previously gained when he studied under the eminent Daśabalakāśyapa and had attained the first contemplation (dhyāna) at that time. In the standard Buddhist literary trope, Saakyamuni informed the monks that this was not the first time Devadatta had lost the power he had obtained from Daśabalakāśyapa: ${ }^{27}$

Sanghabhedavastu 2.86; To. 1, 'dul ba vol. nga, fol. 171a1 f.

bhūtapūrvam bhikṣavo vārānasyām nagaryām brahmadatto nāma rājyạ̣ kārayati ṛddham ca yāvad ākìrnabahujanamanuṣyam ca; (87) tatra candālo vidyāmantradharo vidyāmantrakuśalah gāndhārīvidyām parivartya ṛddhyā gandhamādanāt parvatāt akālartukāni pușpaphalāny ādāya rājñe brahmadattāyopanayati; rājā brahmadattas tasyābhiprasannah abhisāram anuprayacchati;

Previously, O monks, Brahmadatta reigned in Vārānasī, and the town was filled with prosperity, the many people scattered about the city. There, resided one outcaste (candāla), possessed of vidyāmantras, skilled in vidyāmantras, and by invoking the Gāndhārī spell, through his magic power he would bring from Mt. Gandhamādana each day flowers and fruit out of season, and present them to King Brahmadatta. King Brahmadatta, pleased with the outcaste magician, [each day] bestows on him a present.

yāvad anyatamo mānavo mantrārthī mantragaveși śravaparampayā janapadāt vārānasìm anuprāptah; tato mārgaśramam prativinodya tasya candāalasya vidyāmantradhārinạ sakāśam upasaṃkrāntah; upasaṃkramya kathayati: icchāmy aham upādhyāyasya śuśrūṣạ̣̄̄ kartuṃ; kasyārthe? vidyāyāh; sa gāthām bhāsate:

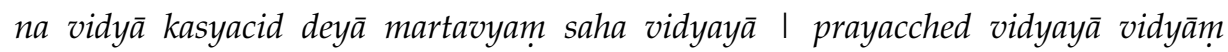
śuśrūṣäbhir dhanena vā | | iti

Now one [brahman] boy (mānava) [Somaśarma] among many desired mantras, was in search of mantras. He heard by word of mouth [about the candāla] and leaving his country

27 This story has been translated by Von Schiefner (1906, pp. 288-91) from the Tibetan Mūlasarvāstivādavinaya. 
made his way to Vārānasī. Having recovered from the toils of the road, he proceeded into the company of the candīla who possessed the spells. Having come before him, he said, "I would like, O Master, to perform service for you?" "For what reason?" "For the spell." He [the candāla] then recited this verse:

The spell is not to be given to anyone; one should die with the spell.

Or one would exchange the spell for [another] spell, or service or wealth.

sa kathayati: upādhyāya yady evam aham śuśrūṣām karomi; kiyantam kālaṃ kartavyā? sa kathayati: dvādaśabhir varșaih śuśrūusayāa dīyeta vā na vā; so 'tyarthạ̣ vidyāpratipannah anujñātavān; tata ārādhanaparamah satkṛtya guruśuśrūṣạ̣̄̄ kartum ārabdhah;

The brahman inquired, "Master, if thus I am to render service [for the spell], for how long does it need to be done?"

The outcaste responded, "With twelve years of service, I will see if the spell is to be given, or not!"

Thus, because the brahman was excessively dedicated to obtaining the spell, he agreed to these terms. From then on, he was dedicated to service, and having paid homage to the outcaste, he began to provide service to the guru.

yāvad aparena samayenāsau canḍ̄alo madyamadākșipto gṛham ägatah; sa mānavah saṃlakṣayati; ayam upādhyāyah atīova madyamadākșiptah; pārśve asya śayyā kalpayitavyā iti; yāoad asau cand̦ālah samparivartitum ārabdhah; tasya samparivartamānasya khațāyā anganikā bhagnā; mānavah śrutvō pratibuddhah; sa saṃlakșayati: upādhyāyah duhkham śayișyate; yannv aham añganikāyām pṛ̦țham datvā avasthitah;

This went along until, on another occasion, the outcaste came home dead drunk on spirits, and the brahman thought to himself, "The teacher is totally drunk, so I should set his bed at my side." [in case he could overhear the spell spoken in his sleep] So then the outcaste began to turn over in his sleep, and while he was doing so, the leg on his bed shattered [so the teacher started to fall off]. The brahman boy heard it and woke up. Then he thought, "The teacher will be sleeping with discomfort. So I should set it so that the legs of the bed are on my back."

dharmatā hy eșā śaundānām yo balavāṃs tasya vāntir bhavati; tasya prathame yāme madyam vigacchati; tena tīkṣnamadyavegāt mānavasya prșthe vāntam; sa samlakșayati: yady aham kāyam cālayeyam vācam vā niścārayeyạ̣ sthānam etad vidyate yad upādhyāyah śabdam śrutvā pratibuddho na punah śayyām kalpayet; sa pratisañkhyānena avasthitah;

Naturally, anyone who has drunk a lot of spirits will vomit, and so in the first watch of the night that booze came back up. And because of the intensity of the spirits, [the candāla] vomited onto the back of the brahman boy. And the boy thought, "If I move my body or utter a sound, then it will be the basis for the teacher, having heard the sound, to wake up. Moreover, if he wakes that way, he won't let me have my bed by him anymore." So he just sat there and ruminated on his situation.

yāvad candālah svayam eva pratibuddhah paśyati tam tathā viprakrtạ̣; tatah prcchati, ko 'yam; sa kathayati: upādhyāya aham somaśarmā; vatsa (88) kim asy evamsthitah? tena yathāorttam samākhyātam;; so 'bhiprasannah kathayati: vatsa paritușto 'haṃ; gatvā snātvā āgaccha; vidyām tubhyam anuprayacchāmi iti; somaśarmā āgatah; tena tasmai vidyā dattā;

In the meanwhile, the outcaste woke up just on his own and saw the brahman there contaminated in that way. "Who are you?" he asked. "Master, it is I, Somaśarma." "Boy, what are you doing there?" So the brahman recounted the story, just as it happened. The teacher was very pleased and exclaimed, "Boy, I am very pleased with you! Go take a bath, 
and then return. I will bestow on you the spell you desire." Somaśarma did as instructed and returned, and the spell was conferred on him.

capalā brāhman̄a bhavanti; sa vegam asahamānah cintayati; ihaiva tāvad enām vidyām jijñāsayāmi, tato 'nyatra gamișyāmi iti; tena sā vidyā parivartitā; bhavanatalam utpatya, āśv eva gandhamādanaṃ parvatam gatvā, akālartukāni pușpāny ādāya āgatah; tena tāni rājñah. purohitāya dattāni; tenāpi rājñe brahmadattāya; rājā kathayati: kutas tavaitāni;

Yet, we know that brahmans are fickle. Unable to contain himself, he quickly thought, "I have to try out this spell that I have just here received! I will travel elsewhere." So he cast the spell and ascended from the surface of the earth. ${ }^{28}$ Having gone to Mt. Gandhamādana, he seized some flowers that were out of season (back in Vārānasī) and then returned (to the palace) and gave them to the King's chief priest (purohita), who in turn gave them to King Brahmadatta. The king exclaimed, "From where did these come?"

sa kathayati: viprakrșțād deśān mānavo 'bhyāgatah; tenaitāni mama dattāni; sa cātyartham vidyāmantradhārī akāmakaran̄ìyaś ca brāhmaṇah; kim anena canḍ̄̄lena sarvalokapratyākhyātena? tasya v̛rttim ācchidya asmai mānavāya dīyatām iti; rājā kathayati: evam kāraya iti; tatah purohitena candāāād vrrttim ācchidya tasmai brāhmanāya dattā; sa tayā akrtajñatayā tasya vidyāyāh parihīnah.

The Purohita replied, "A boy came from a distant place, and he gave these to me. Moreover, he is an extraordinary possessor of vidyāmantras, and a brahman who will not be disappointing. Why do we put up with this candāla, who is despised by the world? Withdraw this position from him, and give it to this boy!" The king replied, "Let it be so!" Then the chief priest withdrew the position from the outcaste and gave it to the brahman youth. However, because of his ingratitude to the outcaste magician, his magical spell ceased to function."

Yijing's Chinese translation is even more explicit in the Somaśarma's denial of the relationship with his candāla teacher:

T.1450.20.173a28-b2:其旃茶羅報國王日。此摩納婆是我弟子。法可過勝我。時國王問摩納 婆。汝今法。可是旃茶羅教不。時摩納婆答大王日。我自苦行一年日夜不。求得此法。旃 茶羅可與我。

In response [to his being fired], the candāla went to the king of the county and said, "This brahman boy is my disciple - how could his mantra ritual be considered superior to my own?" Then the king asked the brahman boy, "Now your mantra ritual, is that one you studied with the candāla or not?" However, the brahman boy replied, "I myself practiced furiously night and day for a year without a break, sought out and obtained this ritual. Now, this cand̄āla falsely claims me [as his disciple]?"

The engaging narrative rings a bit dissonant in some ways, as it tries to identify Somaśarma's loss of the power of a spell with Devadatta's loss of power from his initial obtaining success in the first contemplation (dhyāna). Thus, it sets in analogy two different systems: the one narrative involves a spell that could be overheard by accident and bestows power immediately, while the other story investigates a psychic power gained through assiduous meditative effort over a lengthy period of practice. In some sense, the episode appears to echo the hermeneutic tension found within the Mendaka family story, mentioned above. Moreover, the peculiar structure of the Sanghabhedavastu narrative is clearly artificial, as the text depicts Devadatta as having already lost his power once before, explained in an entirely different manner (Sainghabhedavastu 2.72). As the second story on his loss of

28 Reading bhuvanatalāt instead of bhavanatalam, but neither is attested in the Chinese or Tibetan, both of which eliminate the phrase: nam mkha' la 'phangs nas; T1450.24.173a19: 空騰即已. 
power is both redundant and discordant, so we may assume that this candāla pericope as an editorial intrusion into the earlier narrative of Devadatta's grievous missteps. It appears to be an attempt to identify inter-caste rivalry and brahmanical hubris, with the corruption of spirituality in Devadatta's association with Ajātaśatru and his usurpation of authority over the members of the Samgha, in order to divide the Samgha and displace the Buddha himself.

Yet the engaging narrative certainly has some truth to it, part of the reason it resonates so strongly and is expanded within Yijing's translation. There can be little doubt that we see in Buddhist and Jain literature various outcaste or tribal peoples attributed the possession of spells at different times and places. Yet we seldom find such a distinctive display of caste prerogative as in this instance, a bald-faced subversion of his teacher by Somaśarma to deny the source of his spells and displace his master as the king's own sorcerer. Moreover, the collusion of the royal purohita is emblematic of the community scope of Somaśarma's subversion, for the brahman boy's ability to secure the coveted government sinecure is entirely dependent on the active complicity of his fellow brahman, one who would much rather deal with the high-status personality of Somaśarma than having regular involvement with a polluting outcaste. The king's agreement is a function of the royal-religious/kșatriya-brahman relationship, and the king's only qualms emerge when received systems of authority (guru-disciple) might appear to have been subverted by Somaśarma.

I would submit that much of this kind of behavior actually occurred, perhaps as episodes in the courts of classical and medieval India, but also within the public consciousness, both in the early medieval period and now, with the current defense of received traditions over critical historical inquiry. As Glucklich observed in the modern period, "They [magicians] may imitate the elite traditions, and they may contest elite power, but the reverse is often true as well. Priests in major temples (e.g., Viśvanāth Mandir in Banaras) often utilize magical practices ... " (Gluchlich 814). Once the well-placed brahmans—or Buddhist elites—obtained mantras employed by the mātangas or the candālas, in collusion with purohitas and other agents of caste Hindu practice, they then sometimes would perform what we now recognize as historical erasure: they would simply eliminate their sources from public consciousness by writing them out of their Sanskritic texts. Others might appropriate the spell at the expense of living representatives, even while acknowledging the tribal origins to establish an aura of authenticity. Consequently, we find texts ostensibly with a tribal/outcaste connection represented in the title, yet entirely under the aegis of brahmans, sadhus or Buddhist monks.

\section{Ancient to the Modern}

That there is some measure of continuity in magicians' conduct-whether simply within ritual or exhibited in a larger behavioral vein-extending from the ancient into the modern period is both evident and interesting. Some of the nomenclature reaches back to that reported in the early Buddhist and Jain textual traditions, and the designation of magicians as "tricksters" (kautuka, kuhaka, koüya) is an enduring theme. Cognate with and-in Sanskrit at least-derived from the word for curiosity or amazement (kutuka), things that are kautuka are big displays that incite wonder, and this use is found throughout Sanskrit literature. However, kautuka and related words also signify those who put on a deceptive show, and this use is mentioned as an unacceptable lifeway in the Brahmajālasutta (Dīghanikāya 1.8.29; Sumañgalavilāsin̄ 1.91.28-29), but neither it nor the commentary provide much information. Obscure but better in many regards is the Bhrhatkalpabhāsya (1309), which defines those earning a living by kautuka methods as: $:^{29}$

29 Bollée (1998, vol. 3 s.v.) deals with the peculiar vocabulary of this list, explanations drawn in some measure from the Bṛhatkalpabhāṣyaựtti, vol. 2, p. 403:bālādīnāṃ rakṣādinimittạ̣ striyā vā saubhāgyādisampādanāya yad viśeșena snapanam tad visnapanam I homah śāntikādihetor agnihavanam I śirah parirayaḥ karabhramaṇābhimantranam ādiśabdaḥ svagatānekabhedasūcakaḥ kṣāradahanāni tathāvidhavyādhiśamanāyāgau lavaṇaprakṣeparūpāṇi dhūve a tti tathāvidhadravyayogagarbhasya dhūpasya samarpaṇam I asadrśaveșagranaṇaṃ nāma svayam āryặ sann anāryaveșam karoti puruṣo vā svaṃ rūpam antarhitya strīveșaṃ vidadhātītyādi I avayāsaṇaṃ vṛ̣ksādīnām ālingāpanam avastobhanam aniṣtopaśāntaye niș̣̂īvanena thuthukaraṇam bandhạ̣ kaṇdakādibandhanam etad sarvam api kautukam ucyate | | 
vinhavana-homa-siraparirayā̈̈ khāradahanāïṃ dhūve ya I

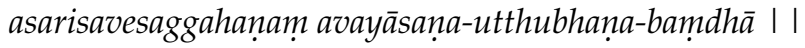

Sprinkling, fire sacrifice, [sanctification by] the circulation of the hand around the head, etc., burning caustic salt and so on, applying incense,

Adopting an inappropriate appearance [e.g., appearing low class/different gender when not], embracing [trees, etc.], spitting [to ward off evil], binding [protective items on the body]: [these are 'tricky' forms of livelihood].

The disparate nature of these behaviors seemed to have led to the term kautuka being applied in two ritual ways. One is found in some of the late grhyasütras and vidhāna literature and extends from the "binding" (bamdhā) application mentioned in this verse. There, kautuka identifies a thread bound on the wrist, either in the case of marriage (Āgnivesyagrhyasūtra 2.3.5) or in the case of a protection ritual for a king involving a thread of gold (Śaunakīya 2.11.5: sauvarnam brahmasūtrakam). This was perhaps understood as a 'amazing/miraculous thread' and the binding of the kautuka becomes a trope in some dramatic literature, so that the Raghuvamsśa 9.1 mentions the vivāhakautuka, and Svapnavāsavadatta at the end of act two employs it as a sign for the completion of the marriage rite (p. 68: koduämangalam kādavvaṃ). In the Mānavagrhyasütra 1.9 .30 and elsewhere kautuka is understood to designate some kind of room or building, wherein the thread ceremony is to take place (Dresden 1941).

More significant for our purposes is the magical-ritual semantic value, so that in several tantric or sectarian sources, the term is united with "illusion" to form a compound: illusion-magic (indrajālakautuka). ${ }^{30}$ Given the conduct of illusionists we have seen, we would expect that the compound would indicate sleight of hand, or the creation of illusions by suggestion. However, that is not what the texts do, by and large. The corpus of illusion-magic consists of innumerable small rituals with immediate outcomes: protection from animals or humans, the ability to be invisible, control of all kinds of people, the use of plants and animal parts for these purposes, the expulsion of enemies and generally the manipulation of the nature of things. Their structure strongly differentiates them from the later Vedic optional ritual literature, the vidhāna texts. In this latter category, for each specific ritual action, there is generally a different mantra invoked, and often a different god. In distinction, here there is most often a single mantra identified, and the ritual applications of this mantra are extraordinary, with a plethora of additions depending on the text, and few specific gods invoked at all. ${ }^{31}$

Moreover, they operate in a coercive universe, in which the sādhaka is supreme. ${ }^{32}$ He does not propitiate gods or spirits in advance of the rite or make offerings or beseech the divinities to hear his petition. There is no panegyric to the god or lauditory hymn that was in an earlier generation termed henotheism, so that each god is said to be special. Here, the magician simply performs the ritual, makes the offending element/spirit/person change course and then is done with it. There is a hard core engineering element to the rite: Squeaky wheel? Grease. Mechanism out of kilter? Mantras to the rescue. Patron needing victory? Perform the rite so that he gets victory and at the same time is brought under the magician's sway (vaśikarana). Occasionally, in the aftermath, the sorcerer may offer to the

30 Sections devoted to this topic are found in Uddāmareśvaratantra, pp. 165-72 (apparently an appendix to the text), Bṛhat-indrajāla, pp. 63-64 (the introduction to Dätātreya ch. 11 and mantra), Udúlísatantra, pp. 97-123 (chapter 10). In the Kakșaputa attributed to the siddha Nāgārjuna, the terms are unbound, so that chapter 13 (pp. 338-48) in the printed edition is the indrajāla chapter, whereas two chapters of the vulgate edition are entitled as devoted to kautuka-chapter 12 (pp. 335-38) and chapter 20 (pp. 384-90) but this last is actually listed in its chapter colophon as sarvasamkhyāsādhana; for the manuscript chapters see (Yamano 2013, pp. 63-64; Wujastyk 1984).

31 The Amoghapāśamahākalparāja operates in much the same manner, constantly referencing the Amoghapāsahrdaya as its basic mantra recitation to be employed in a wide variety of means. The list could be expanded, for many tantric texts do the same. The primary place where this structure is not observed in the indrajāla texts is in the invocation of the many yakșinīs, each of which has their own mantra; e.g., Dattātreyatantra chapter 12, pp. 159-62; Uḍ̂amareśvaratantra, pp. 88-106, etc. Even the Niśvāsatattvasamhitā's oldest section, the Mūlasūtra, affirms the multiple use of a single exceptional mantra: paramantraprayogena sarvakarmāni kārayet || $7.15 \mathrm{~cd}$.

32 Davidson (2017) studies the sorcerers and coercive magic in the context of an early pre-tantric Buddhist text propitiating the nāgas for the purpose of rain. 
spirit in question, but this is a reward at the conclusion rather than a request at the beginning. We get little sense of the theology of the sādhaka's relationship with divinity (tattva, kalā, vyūha, etc.), the yoga of identity, the emotional or yogic or meditative relationships that lead into bhakti at a later date. Here, it is sorcerer to the rescue, with the proper tools at his disposal, which is why the ritual literature is so specific concerning the materials to be employed, much as a physician is specific in medical practice: this herb/animal-part/element, not some other item, is to be used.

These later texts are in need of extensive study, and vary widely one from the other but a small sample from the Illusion-magic chapter (chapter 11) of the Dattātreyatantra will suffice. ${ }^{33}$ For the mantra at the head of the chapter-OṂ NAMO NĀRĀYANĀYYA VIŚVAMBHARĀYA INDRAJĀLAKAUTUKĀNI DARŚAYA DARŚAYA SIDDHIM KURU KURU SVĀHĀ—several dozen rituals are provided, depending on the textual recension. ${ }^{34}$ One ritual is simple:

ulūkasya kapālena ghṛtenāhrtakajjalam I tena netrāñanam kṛtvā ratrau paṭati pustakam I I $11.8^{35}$

Having made a salve for the eyes with lampblack mixedwith ghee in the skull of an owl, he can read texts at night.

If reading texts at night is not required, and the sādhaka does not actually wish to recite the mantra, then another source of accomplishment is available.

sarpadantạ̣ gṛhìtvā tu krṣnavrọścikakaṇtakam I

kṛkalāsaraktayuktam sūkṣmacūrnạn tu kārayet I |

yasyānge nikṣipec cūrnam sadyo yāti yamālayam I

vinā mantreṇa siddhih syāt siddhiyoga udāhrtam | | $11.36^{36}$

Having taken a snake's tooth, and the stinger of a black scorpiontogether with blood of a chameleon, make a fine powder.

If you put this powder on someone's limbs, then he will immediately go to the abode of Yama (i.e., he will die).

Let this be siddhi without the mantra, and let it be designated 'siddhayoga'. ${ }^{37}$

As is clear, the mantra is derived from Nārāyaṇa, even though the Dattātreyatantra is nominally Śaiva, as most of the later texts are. However, there is actually precious little Śaivism in many of them, and in reading them we are reminded of the multi-faceted personality of Dattātreya in Indian history overall (Rigopoulos 1998). In the tantra sporting his name, he seems to have become a ritual category for the aggregation of magical rites.

What is notable in these works is that they reflect much of the early descriptions of the substance of the sorcerers: the use of birds—especially crows, peacocks and owls—the emphasis on small images

33 The numbering is from the Indrajālavidyāsamgraha edition, (pp. 132-65); the organization and most of the readings from this edition are verified in Dattātreyapatalah fols. 26b-39b3. The Tripāthī edition and Hindi translation is from an entirely different recension, and it is not clear to me whether this is bowdlerized or a simple series of eye-skips. The sense that this chapter might not be entirely acceptable in some circles is supported by the Dattātreyatantra, Dharmarthi Trust ms. 4913, fol. 8 b concludes chapter 10, whereas fol. 9a begins chapter 12, thus droping out the entire chapter.

34 Lest the use of the term kautuka is considered anomalous in this chapter, the tantra concludes its first chapter with a mantra that is to stand as the basic one: om param brahma paramātmane oṃ namah utpattisthitipralayakarāya brahmahariharāya trigunātmane sarvakautukāni darśaya dattātreya namah tantrāṇi siddhim kuru kuru svāhā. Moreover, statements about the applicablility of kaukuta are repeated throughout parts of the text, starting with the outline of the text, chapter 1.14-17, to which this mantra is to be applied.

35 Tripāthī (1995, p. 152) reads: ullūkasya kapāle tu ghṛtadīpena kajjam I pātayitvāṃjayen netre rātrau paṭhati pustakam I | Dattātreyapatalah fol. 28a4-5: ulūkasya kapālena jrtena ha kajalam tena netrāmjanam krtvā rātrau pathamti pustakam.

36 Tripāthī omits this verse, jumping from Indrajālavidyāsamgrah p. 155, vv. 35 to 40, omitting vv. 36-39. Dattātreyapatalah fol. 33a4-b1: sarpadaṃtạ̣ gṛhītvā tu kṛ̣nnavṛ́cikakaṃṭakaṃ kṛkalāraktasaṃyuktạ̣ sūkṣmacūrṇam tu kārayet yasyāmme nikṣipec cūrṇaṃ sadyo yāṃti yamālayam I |

37 This line about this or that ritual being siddhayoga is often encountered in the Dattattreyatantra; e.g., pp. 138, 139, 141, etc., so that this one verse should not be considered definitive of that category in this text. 
of demons and planets, the use of rural ingredients, all are in accord with the suggestions about the yātudhānas in the Vedic corpus and their ritual afterlife. The fact, demonstrated long ago, that the term $y \bar{a} t u$ survives in the modern North Indian $j \bar{a} d \bar{u}$ would seem to indicate some kind of tradition that survived outside of the literate sphere per se, even if it was included in ostensibly sectarian literature at some date.

Perhaps just as important as substance, is the issue of style, which I would argue is one of the magicians' contributions to the tantric ritual and literary practice. Because so many of these rituals are without any specific moral imperative, they may be employed for all kinds of purposes. And because they are tools to various ends without a theological architecture, they may glide into a variety of sectarian frameworks: changing the mantra, visualizing the deity, dedicating the merit, requiring $d \bar{\imath} k s \underline{\bar{a}}$ (which most do not even mention let alone describe), invoking vows, etc. Yet they also may be vehicles to allow aggregation from other sources-folk traditions, new inventions, rumors of power elsewhere. In the most extensive study of a South Asian sorcerer tradition, Kapferer emphasizes its simultaneously creative and appropriative style among the sorcerers he knew.

There is a widespread view that innovative or foreign sorcery practice is more likely to achieve desired results. This is because antidotes to its poison (vasa) are not developed. There is a great tension to innovation and borrowing in sorcery practice: it is the space of the bricoleur par excellence ... The culture of sorcery is alive to borrowing and invention, and the more foreign or strange the practice, the greater its potency for death and destruction. (Kapferer 1997, p. 46)

I believe we see all of these activities in medieval Indian tantrism, with its cross-tradition borrowing, its emphasis on power, its desire for the foreign, tribal or extra-terrestrial aura and so on. The references to mätanga or śabara tribal peoples in the tantras are analogous to the modern appropriation of tribal charisma by non-tribal sorcerers, most evident in the designation 'baiga' in Chhattisgarh and Madhya Pradesh. ${ }^{38}$ Some of these elements, to be sure, become rationalized in selective texts and traditions, and in many instances we find a strong moderation of the magical element merging into the religious element, with its distinctive emphasis on the dynamic relationship between deity and devotee. Yet this is most often accomplished via an elaborate, elite hermeneutic that is not encoded in the basic ritual action but operates as a symbolic frame of reference, one that can be modified even while retaining the ritual event. That is not to say that the symbolic frame is insignificant, nor is the community supporting it an afterthought. Rather, it is to acknowledge that rituals of power tend to operate in a value-neutral moral ground, and those adopting that ground must furnish it with a system of value predicated on their own traditions.

\section{Conclusions: Sorcerers as Continuing Sources for Tantric Systems}

If the above treatment is somewhat superficial-and in the face of the very sophisticated discussions of Kapferer, Tarabout, Nabokov and others, I certainly acknowledge that it is-this is in part because the volume of evidence is enormous and the intellectual challenges in unpacking and interpreting that evidence are daunting. Unlike anthropologists, textual scholars do not have the luxury of interrogating our informants about their intentions or other aspects of their performances. Here, I do not presume to have done more than bring to the attention of my colleagues some of the materials available.

Yet the evidence suggests-both from the examples given and from the many others for which space prohibits discussion - that there existed in India from the ancient to the modern period various

38 On tribal sorcerers, representative are Fuchs (1973), Sinha (2006) and Rahmann (1959), but the bibliography is quite lengthy; on the Baiga magicians in particuar, Elwin (Elwin 2007, pp. 305-407) and Babb (1975, pp. 197-208), demonstrates that, in the communities he studied, baiga is no longer a tribal designation but a form of employment, exclusively engaged in by non-twice born castes. 
groups and individuals operating under a variety of designations; these people pursued avocations we would recognize as sorcery, magic or other ritual forms of the manipulation of reality for personal or professional reasons. The categories we find-yātudhāna, ikṣaṇika, vidyādhara, d̦ākinī, aindrajālika, $m \bar{a} y \bar{a} k \bar{a} r a$ - cannot be expected to reflect precisely the fluid categories and reality on the ground while the texts were in the process of formation. Instead these designations most likely represent the literary reification of a bewildering variety of pursuits, often outside of our received lineal or ritual categories. That is because these individuals were not necessarily based in a lineage or literature themselves, and most of them are depicted as operating outside of the aura of polite society or of received linguistic norms, even if some were patronized by king and court. Like their modern successors-jādūgar, ojha, dāïn, baiga, mantravādi, cāmis, etc.- -they did not hold themselves aloof from the gritty necessities of making a living. Instead they pursued their claim to the manipulation of the cosmos in service of either personal promotion or their patron's goals. We may suspect that their employment of various kinds of lethal rituals in the ancient and medieval period was accompanied with other forms of lethality less metaphorical and more physical, but this is a suspicion that requires further investigation, as do virtually all aspects of their activity. Certainly, sorcerers are occasionally depicted as creating and enjoying conflict, whether between friends or enemies, so we may assume that they were part of the predisposition to interpersonal drama in Indian social life.

Some of them evidently saw themselves as operating in a lineage, obtaining some kind of initiation from a teacher, even if we suspect (as the modern evidence supports) this may have been secondary or tertiary to their motives for the pursuit of their vocations. It is also entirely possible that "initiation" or guru-disciple relationship may have been the stuff of visions, dreams, or just fabricated out of the thin air of the mountain regions said to be inhabited by the vidyādharas in Jain narratives. Some, to be sure, felt called through some kind of personal crisis or psychological event (Nabokov 2000, pp. 149-51). However, just as likely, others simply understood a possibility and pursued a livelihood where none was otherwise available, relying on their social skills, understanding of patronage and motivation, and verbal wit to pull them out of uncomfortable situations. Moreover, because this is a function of human behavior, we may surmise that others came to their calling at a time of social dislocation and economic uncertainty, when no other form of economic support was available. Irrespective of cause, the documents invariably speak of the search for control, of the need for sustenance, of the understandable desire for the basic elements of human life.

It is also clear from the available evidence that identifying any of these as necessarily "Buddhist," "Śaiva," "Vaiṣnava," "Jaina" or "Sākta" is to misrepresent our sources, for the many instances of the lifeways delineated in the literate record seldom identify these magicians with any sectarian system of allegiance that is the sine qua non of modern Indological narrative. We may reflect on the fact that the literate archive is not so transparent, not immediately evident, not uncritically accessible as it has been occasionally treated in scholarly literature. This appears perhaps a weakness of some Indological understanding, based on a limited vision of what constitutes admissible categories. However, it is not a misrepresentation within the sources themselves, which consistently maintain a complex understanding of their own periods.

At no time for which we have evidence in India do we see magicians or sorcerers as relinquishing the field, nor are they ever under the domination of any single sectarian lineage. Indeed, in the modern period, they cross religions as well as traditions, with some coming from Islamic disenfranchised social groups, employing the opportunities available (Shah 1998; Tarabout 2000). Thus, we must take into account that these figures were invested with spells that were claimed to allow them supernormal powers, raise the dead, heal the sick, cast spells of benefit and destruction and counter other sorcerer's spells for own patrons. They left us only tantalizing clues of their existence, they generally came from a vernacular background, and were dedicated to their own welfare as much as their promulgation of alternative rituals.

And yet these clues equally raise the specter of historical erasure: the intentional or unintentional occlusion of non-elite or non-brahmanical elements, all in service of the dominant paradigm. The 
hostility of some brahmanical representatives to even discussing the religious traditions of those on the margins of society has been expressed to anthropologists. As Sax was told when he tried to present some outcaste data on ritual healing in Delhi, "How dare you conduct research on such a topic? . . . You should be spending your time stamping out this sort of thing, not conducting research on it!" ((Sax 2009, p. 232); see also (Nabokov 2000, p. 149)) So non-literate magical rituals among marginalized communities continue to be eliminated from discussion right into the present, much as they have been within India's past. If there is a critical imperative, we might acknowledge that the forces of elite privilege did not only arise as a result of capitalist commercial or post-colonial forces, but equally stem from deeply seated symbol and social systems that have been reiterated throughout Indian history.

Acknowledgments: I wish to thank the Steering Committee of the Society for Tantric Studies for their gracious invitation to provide the keynote address that was the basis for this paper. I especially wish to thank Glen Hayes who kindly thought of me, as well as Paul Donnelly, who hosted the event at Northern Arizona University.

Conflicts of Interest: The authors declare no conflict of interest.

\title{
Abbreviations
}

\author{
AVŚ. Atharvaveda Śaunakīya. \\ RV. Rgveda. \\ T. Taishō Shinshū Daizōkyō. Takakusu Junjirō and Watanabe Kaikyoku, eds. \\ 1924-35. Tokyo: Daizōkyōkai. \\ sDe-dge canon numbers from Ui, Hakuju, et al., eds. 1934. A Complete \\ To. \\ Catalogue of the Tibetan Buddhist Canons (BKah-hgyur and Bstan-hgyur). \\ Sendai: Tôhoku Imperial University.
}

\section{Bibliography}

\section{Primary Sources}

Āgniveśyagṛhyasūtra. Ravi Varma, L. A., ed. 1940. Āgniveśyagṛhyasūtra. Trivandrum Sanskrit Sries No. 144. Trivandrum: Bhaskara Press.

Amoghapāśamahākalparāja. Kimura, Takayasu, et al., eds. 1998-2011. Transcribed Sanskrit Text of the Amoghapāśakalparāja. Taishō Daigaku Sōgō Bukkyō Kenkyūjo Nenpō (大正大學綜合佛教研究所年報) vol. 20 (1998), pp. 1-58; vol. 21 (1999), pp. 81-128; vol. 22 (2000), pp. 1-64; vol. 26 (2004), pp. 120-183; vol. 32 (2010), pp. 170-207; vol. 33 (2011), pp. 32-64. T. 1092, To. 686. Trans. Bodhiruci II 707 CE.

Anggavijjā. Punyavijayaji, Muni Shri, ed. 1957. Anggavijjā (Science of Divination through Physical Signs and Symbols). Prakrit Text Society Series No. 1. Banaras: Prakrit Text Society.

Arthaśāstra. Kangle, R. P. 1965. The Kauțilìya Arthaśāstra. 3 parts. Bombay: Bombay University.

Atharvaveda Śaunakīya. Bandhu, Vishva, ed. 1960-1962. Atharvavedah Śaunakīyah. Vishveshanand Indological Series 13-16. Hoshiarpur: Vishveshvaranand Vedic Research Institute.

Āvaśyakaniryuktyavacūrṇi. Pramodasāgara, Pạ̣ Probodhasāgara Śiṣyamuni. 1974. Śrīmatī Āvaśyakaniryuker avacūrṇih. 2 vols. Śreșthidevacandralālabhāï-Jainapustakoddhāre Granthākaḥ vol. 123. Surat: Śreșthidevacandralālabhāi-Jainapustakoddhāra.

Bhadramāyākāravyākaraṇa. Régmey, Konstanty. 1938. The Bhadramāyākāravyākaraṇa: Introduction, Tibetan Text, Translation and Notes. Warsaw: Warsaw Society of Sciences and Letters. Rpt. Delhi: Motilal Banarsidass, 1990.

Bhāgavatapurāna. Shastri, H. G., ed. 1996-2002. The Bhāgavata [Śrīmad Bhāgavata Mahāpurāna] Critical Edition. 4 vols. Ahmedabad: B. J. Institute of Learning and Research.

Bhaiṣajyagurusūtra. Dutt, Nalinaksha, ed. 1939. Gilgit Manuscripts. vol. 1, pp. 1-32. T. 449. To. 504.

Bodhicaryāvatāra. La Vallée Poussin, Louis de. 1901-1914. Prajñākaramati's Commentary to the Bodhicaryāvatāra of Çāntideva. Bibliotheca Indica vol. 150. Calcutta: Asiatic Society of Bengal.

Bṛhat-indrajāla. Tripathi, Harihar Prasad, ed. 2015. Vṛhat Indrajāla with 'Hari' Hindi Commentary. Krishnadas Sanskrit Series 191. Varanasi: Chowkhamba Krishnadas Academy. 
Bṛhatkalpabhāṣya. Bollée, Willem B., ed. 1998. Bhadrabāhu Bṛhat-Kalpa-Niryukti and Sanghadāsa Bṛhat-Kalpa-Bhāṣa: Romanized and Metrically Revised Version, Notes from Related Texts and a Selective Glossary. 3 parts. Beiträge zur Südasienforschung Suudasien-Institut Universität Heidelberg, Band 181, 1-3. Stuttgart: Franz Steiner Verlag.

Bṛhatkalpabhāṣyaựtti. Malayagirisūri (\& Kṣemakīrti). Caturavijaya and Pụ̣yavijaya, eds. 2002. Sthavira-Āryabhadrabāhusvāmipran̄îtasvopajũa-niryuktyupetạ̣ Bṛhat Kalpasūtram. 6 vols. Śrī-ĀtmānandaJainagrantharatnamālā 82. Bhāvanagara: Śrījaina-Ātmānandasabhā.

Bṛhatkathāślokasamgraya. Lacôte, Félix, ed. 1908. Budhasvāmin Bṛhat-Kathā Çlokasamgraha. Paris: Imprimerie Nationale.

Bṛhatsaṃhitā. Dvivedī, Kṛṣna Candra, ed. 1996-1997. Bṛhatsaimhitā by Śrī Varāhamihirācārya, With the Commentary of Bhaț̣totpala. Sarasvatībhavana-Granthamālā vol. 97. 2 parts. Varanasi: Sampuranand Sanskrit University.

Dattāreyatantram. In Indrajālavidyāsaṃraha, pp. 132-65. Tripāṭhī, Rudradeva, ed. 1995. Dattātreya-Tantra. New Delhi: Ramjan Pablikeśans. Dattātreyapațalah. Dharma Trust at Raghunath Temple, Jammu, Jammu \& Kashmir, no. 5602. Available online: archive.org (accessed on 17 June 2017).

Dharmagupta-vinaya-vibhanga. T. 1428.

Dighanikāya. Rhys Davids, T.W., and J.E. Carpenter. 1890-1911. The Dīgha Nikāya. 3 vols. London: H. Frowde for the Pali Text Society.

Indrajālavidyāsaṃgrahah. Vidyāsāgara, Jīvānanda, et al., eds. 1915. Calcutta: V. V. Mukharji.

Jātaka. Fausbøll, Viggo. 1877-1896. Jātaka Together with its Commentary, Being Tales of the Anterior Births of Gotama Buddha. 6 vols. London: [Kegan Paul, Trench,] Trübner \& Co.

Kakṣapuța. In Indrajālavidyāsamgrahah, pp. 265-390; for an edition and translation of the chapter on yakṣinīsādhana, see Yamano.

Lañkāvatārasūtra. Nanjio, Bunyiu. 1956. The Là̉kāvatāra Sūtra. Bibliotheca Otaniensis. vol. 1 Kyoto: Otani University Press.

Mahābhārata. Sukthankar, V.S., et al. 1927-1966. The Mahābhārata. 19 vols. Poona: Bhandarkar Oriental Research Institute.

Mahāvagga. Oldenburg, H. 1879-1883. The Vinaya Pițakạ̣-One of the Principal Buddhist Holy Scriptures in the Pâli Language. vol. 1. The Mahâvagga. London: Williams and Norgate.

Mañjuśriyamūlakalpa. Sastri, T. Gaṇapati. 1920-1925. Âryamanjusrîmûlakalpa. 3 parts. Trivandrum Sanskrit Series, nos. 70, 76, 84. Trivandrum: Oriental Manuscripts Library of the University of Travancore.

Mānavadharmaśāstra. Olivelle, Patrick. 2005. Manu's Code of Law: A Critical Ediion and Translation of the Mānava-Dharmaśāstra. Oxford and New York: Oxford University Press.

Nāradasmṛti. Lariviere, Richard W. 1989. The Nāradasmṛti. 2 parts. University of Pennsylvania Studies on South Asia, vol. 5. Philadelphia: Department of South Asia Regional Studies, University of Pennsylvania.

Nāyādhammakahāo. Vaidya, N.V. 1940. Nāyādhammakahāo [The Sixth Anga of the Śvetāmbara Jain Canon]. Poona: Prof. N.V. Vaidya. Edited by Muni Dīparatnasāgara 2000. Āgamasuttāṇi (Sațīkạ̣): Bhāgaḥ 7, pp. 5-260. Amadābād: Āgama Śruta Prakāśan. Edited and Translate by Upapravarttaka Śrī Amar Muni, et al. 1996. Sacitra Jũātādharmakathāmga Sūtra. 2 vols. Delhi: Padma Prakāśan.

Niśvātattvasaṃhitā. Goodall, Dominic, ed. and trans. 2015. The Niśvātattvasaṃhitā: The Earliest Surviving Śaiva Tantra-Vol. 1. A Critical Edition \& Annotated Translation of the Mūlasūtra, Uttarasūtra \& Nayasūtra. Pondicherry: Institut Français de Pondichéry, École française d'Extrême-Orient, Department of Indian and Tibetan Studies, Asien-Afrika-Institut, Universität Hamburg.

Raghuvamsśa. Devadhar, C.R. ed. and trans. Raghuvamśa of Kālidāsa: Edited with Critical Introduction, English Translation and Notes. Delhi: Motilal Banarsidass Publishers.

Rāmāyana. Bhatt, G.H. et al., eds. 1958-1975. The Vālmīki Rāmāyana-Critically Edited for the First Time. 7 vols. Baroda: Oriental Institute.

Ratnāvalī. Cappeller, Carl. 1909. Otto Böhtlingk's Sanskrit-Chrestomathie: Dritte Verbesserte und Vermehrte Auflage. Edited by Richard Garbe. Leipzig: H. Haessel Verlag, pp. 326-82.

Bhattachary, Ashokanath and Maheshwar Das Kavyatirth, eds. 1939. Ratnavali of Emperor Shri Harsha. Calcutta: Modern Book Agency.

Chakravarti, Sris Chandra. 1902. The Ratnavali: A Sanskrit Drama by Sriharsha. Dacca: Hari Ram Dhar, Ashutosh Library. 
Rgveda. Van Nooten, Barend A., and Gary B. Holland, eds. Rig Veda: A Metrically Restored Text with Introduction and Notes. Harvard Oriental Series vol. 50. Cambridge: Department of Sanskrit and Indian Studies, Harvard University.

Samantapāsādikā. Takakusu, J., and M. Ngai, eds. 1924-1947. 6 vols. London: Oxford University Press for the Pali Text Society.

Samyuktāgama. T. 99.

Sanghabhedavastu. Gnoli, Raniero, ed. 1977-1978. The Gilgit Manuscript of the Sanghabhedavastu: Being the 17th and Last Section of the Vinaya of the Mūlasarvāstivādin, 2 parts. Serie Orientale Roma vol. 49, pp. 1-2. Rome: Istituto Italiano per il Medio ed Estremo Oriente. To. 1, vols. ga, 255b-nga, 302a. T. 1450.24.99a-206a.

Sanmukhakalpa. George, Dieter. 1991. Șaṇmukhakalpa: Ein Lehrbuch der Zauberei und Diebeskunst aus dem Indischen Mittelalter. Monographien zur Indischen Archäologie, Kunst und Philologie, Band 7. Berlin: Dietrich Reimer Verlag.

Sañyuttanikāya. Feer, M. Leon. 1884-1896. Saṃyutta-Nikāya. 5 vols. London: Henry Frowde for the Pali Text Society. Sāratthappakāsin̄̄. Woodward, F.L. ed. 1929-1937. Sārattha-Ppakāsinī: Buddhaghosa's Commentary on the Saๆyutta-Nikāya. 3 vols. London: Pali Text Society.

Śārdūlakarnā̃oadāna. Mukhopadhyaya, Sujitkumar, ed. 1954. The Śārdūlakarnā̄vadāna. Santiniketan: Viśvabharati.

Śaunakīya. Śāstrī, K. Sāmbaśiva, ed. 1935. The Śaunakīya. Trivandrum Sanskrit Series No. 120. Trivandrum: Superintendent, Government Press.

Sumaṅgalavilāsin̄ī. Rhys Davids, T.W., and J. Estlin Carpenter, eds. 1886-1932. Sumañgala-Vilāsin̄̄, Buddhaghosa's Commentery on the Digha Nikāya. 3 vols. London: Henry Frowde for the Pali Text Society.

Svapnavāsavadatta. Rai, Ganga Sagar. 2003. Svapnavāsavadattam of Bhāsa. Kashi Sanskrit Series 296. Varanasi: Chaukhambha Sanskrit Sansthan.

Uḍ̂āmareśvaratantram. 2015. Shukla, Brijesh Kumar, ed. 1996. Uddamareshwar Tantra with 'Shantishwari' Hindi Commentary. Krishnadas Sanskrit Series 149. Varanasi: Krishnadas Academy.

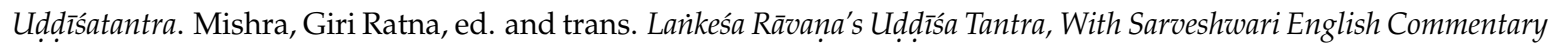
$\mathcal{E}$ Introduction. Varanasi: Chaukhamba Surbharti Prakashan.

Uttarādhyayana. Mahārāj, Bhuvanabhānusūrīśvarajī, ed. n.d. Śrī Uttarādhyayanasūtram. Mumbai: Divyadarśan Trust.

Vāyupurāṇa. Āpṭe, Hari Nārāyaṇ, ed. 1905. Mahāmunišrīmad-vyāsapraṇitam Vāyupurānam. Ānandāśramasaṃskṛtagranthāvalị 49. Punyākhyapattana [Pune]: Ānandāśramamudraṇāyala.

Vāsudevahindidi. Muni Caturvijaya, and Muni Punyavijaya, eds. 1930-1931. Vasudevahinḍi. Śn̄ ĀtmānandaJainagrantharatnamālā, nos. 80 \& 81. Bhavnagar: Shri Jain Atmanand Sabha.

Vinaya. Oldenberg, Hermann. 1879-1883. The Vinaya Pitakam: One of the Principal Buddhist Holy Scriptures in the Pâli Language. 6 vols. London: Williams and Norgate.

Viṣnusmṛti. Olivelle, Patrick. 2009. The Law Code of Viṣnu: A Critical Edition and Annotated Translation of the Vaiṣnava-Dharmaśāstra. Harvard Oriental Series 73. Cambridge: Deparment of Sanskrit and Indian Studies, Harvard University.

\section{Secondary Sources}

Babb, Lawrence A. 1975. The Divine Hierarchy: Popular Hinduism in Central India. New York: Columbia University Press.

Baines, J. A. 1893. Census of India, 1891: General Report. London: Eyre and Spottiswoode.

Balbir, Nalini. 1990. Stories from the Āvaśyaka commentaries. In The Clever Adultress and Other Stories: A Treasury of Jain Literature. Edited by Phyllis Granoff. Oakville, New York and London: Mosaic Press, pp. 17-74.

Balbir, Nalini, and Thomas Oberlies. 1993. Āvaśyaka-Studien. Alt- und Neu-Indische Studien herausgegeben vom Institut für Kultur und Geschichte Indiens und Tibets an der Universität Hamburg, 45, 1 \& 2; Stuttgart: Franz Steiner Verlag.

Bhandarkar, Devadatta Ramakrishna, Bahadurchand Chhabra, and Govind Swamirao Gai. 1981. Inscriptions of the Early Gupta Kings. Corpus Inscriptionum Indicarum III; New Delhi: Archaeological Survey of India.

Blaut, James M. 1987. Diffusionism: A Uniformitarian Critique. Annals of the Association of American Geographers 77: 30-47. [CrossRef] 
Bloomfield, Maruice. 1913. The Character and Adventures of Muladeva. Proceedings of the American Philosophical Society 52: 616-50.

Bronkhorst, Johannes. 2014-2015. The Magas. Brahmavidyā: The Adyar Library Bulletin 78-79: 459-86.

Bruhn, Klaus. 1998. Bibliography of Studies Connected with Āvaśyaka-Commentaries. In Catalogue of the Papers of Ernst Leumann in the Institute for the Culture and History of India and Tibet, University of Hamburg. Edited by Birte Plutat. Alt- und Neu-Indische Studien herausgegeben von Institut für Kultur und Geschichte Indiens und Tibets an der Universität Hamburg, 49; Stuttgart: Franz Steiner Verlag, pp. 119-36.

Byrskog, Samuel. 2007. A Century with the Sitz im Leben: From Form-Critical Setting to Gospel Community and beyond. Zeitschrift für die Neutestamentliche Wissenschaft und die Kunde der Älteren Kirche 98: 1-27. [CrossRef]

Ch'en, Kenneth. 1953. Apropos the Mendhaka Story. Harvard Journal of Asiatic Studies 16: 374-403. [CrossRef]

Collar, Anna, Fiona Coward, Tom Brughmans, and Barbara J. Mills. 2015. Networks in Archaeology: Phenomena, Abstraction, Representation. Journal of Archaeological Method and Theory 22: 1-32. [CrossRef]

Cort, John E. 1997. Tantra in Jainism: The Cult of Ghanțākarn Mahāvīr, the Great Hero Bell-Ears. Bulletin d'Études Indiennes 15: 115-33.

Cort, John E. 2000. Worship of Bell-Ears the Great Hero, a Jain Tantric Deity. In Tantra in Practice. Edited by David Gordon White. Princeton: Princeton University Press, pp. 417-33.

Davidson, Ronald. 2002. Indian Esoteric Buddhism: A Social History of the Tantric Movement. New York: Columbia University Press.

Davidson, Ronald. 2017. Studies in Dhāraṇī Literature IV: A Nāga Altar in 5th Century India. In Consecration Rituals in South Asia. Edited by István Keu. Leiden and Boston: Brill, pp. 123-70.

Davis, Donald R. 2004. The Boundaries of Hindu Law: Tradition, Custom and Politics in Medieval Kerala. Torino: Comitato "Corpus Iuris Sanscriticum et Fontes Iuris Asiae Meridianae et Centralis".

Dezső, Csaba. 2010. Encounters with Vetālas: Studies on Fabulous Creatures. Acta Orientalia Academiae Scieniarum Hungaricae 63: 391-426. [CrossRef]

Dresden, Mark. 1941. Mānavagṛhyasūtra: A Vedic Manual of Domestic Rites-Translation, Commentary and Preface. Groningen and Batavia: Bij J. B. Wolters' Uitgevers-Matschappij.

Edgerton, Franklin. 1953. Buddhist Hybrid Sanskrit Grammar and Dictionary, vol. II: Dictionary. New Haven: Yale University Press.

Elwin, Verrier. 2007. The Baiga. New Delhi: Gyan Publishing, First published 1939.

Elisa Freschi, and Philipp A. Maas, eds. 2017. Adaptive Reuse: Aspects of Creativity in South Asian Cultural History. Abhandlungen für die Kund des Morgenlandes, Band 101; Wiesbaden: Harrassowitz Verlag.

Fuchs, Stephen. 1973. Priests and Magicians in Aboriginal India. Studia Missionalia 22: 201-36.

Glucklich, Ariel. 2012. Jādūgars. In Brill's Encyclopedia of Hinduism. Leiden and Boston: Brill, vol. IV, pp. 806-14.

Goudriaan, Teun. 1978. Māyā Divine and Human. Delhi: Motilal Banarsidass.

Grafe, Jörg. 2001. Vidyādharas_Früheste Zeit bis zur Kaschmirischen Bṛhatkathā. Europäische Hochschulschriften Reihe XXVII Asiatische und Afrikanische Studien; Frankfurt am Main: Peter Lang, vol. 82.

Griffiths, Arlo. 2004-2005. Tumburu: A Deified Tree. Bulletin d'Études Indiennes 22-23: 249-64.

Herrmann-Pfandt, Adelheid. 1996. The Good Woman's Shadow. Some Aspects of the Dark Nature of Dākinīs and Sákinīs in Hinduism. In Wild Goddesses in India and Nepal: Proceedings of an International Symposium, Berne and Zurich, November 1994. Edited by Axel Michaels, Cornelia Vogelsanger and Annette Wilke. Studia Religiosa Helvetica Jahrbuch; vol. 2, Bern: Peter Lang, pp. 39-70.

Huang, Po-chi. 2009. The Cult of Vetāla and Tantric Fantasy. In Rethinking Ghosts in World Religions. Edited by Mu-chou Poo. Numen Book Series: Studies in the History of Religions; Leiden \& Boston: Brill, vol. 123, pp. 211-35.

Jain, Jagdishchandra. 1977. The Vasudevahindi: An Authentic Jain Version of the Bṛhatkathā. L. D. Series 59; Ahmedabad: L. D. Institute of Indology.

Jamkhedkar, Aravinda Prabhakar. 1984. Vasudevahiṃd̄i: A Cultural Study. Delhi: Agam Kala Prakashan.

Kale, M. R. 1921. The Ratnāvalī of Śrī Harșa-Deva. Delhi: Motilal Banarsidass Publishers.

Kapferer, Bruce. 1997. The Feast of the Sorcerer: Practices of Consciousness and Power. Chicago: University of Chicago Press.

Lenz, Timothy. 2010. Gandhāran Avadānas: British Library Kharoṣthī Fragments 1-3 and 21 and Supplementary Fragments A-C. Seattle and London: University of Washington Press. 
Leumann, Ernst. 2010. An Outline of the Āvaśyaka Literature: Translated from the German by George Baumann with an Introductory Essay by Nalini Balbir. Ahmedabad: L. D. Institute of Indology.

Lingat, Robert. 1973. The Classical Law of India. Berkeley and Los Angeles: University of California Press.

Lüders, Heinrich. 1939. Die Vidyādharas in der buddhistischen Lieratur und Kunst. Zeitschrift der Deutschen Morgenländischen Gesellschaft 93: 89-104.

Mitchell, Nathan. 2009. The Mystery of the Rosary: Marian Devotion and the Reinvention of Catholicism. New York: New York University Press.

Nabokov, Isabelle. 2000. Deadly Power: A Funeral to Counter Sorcery in South India. American Ethnologist 27: 147-68. [CrossRef]

Nigam, L. S. 2000. Riddle of Indian Iconography: Zetetic on Rare Icon from Tala. Delhi: Sharada Publ. House.

Bhikkhu Nyanatusita himi, ed. 2013. The Bodhisattva Ideal: Essays on the Emergence of Mahāyāna. Kandi: Buddhist Publication Society.

Parpola, Asko. 1988. The Coming of the Aryans to Iran and India and the Cultural and Ethnic Identity of the Dāsas. Studia Orientalia (Helsinki) 64: 194-302.

Plowden, W. Chichele. 1883. Report on the Census of British India taken on the 17th February 1881. 3 vols. London: Printed by Eyre and Spottiswoode for H. M. Stationery Off.

Rahmann, Rudolf. 1959. Shamanisti and Related Phenomenon in Northern and Middle India. Anthropos 54: 681-760.

Rigopoulos, Antonio. 1998. Dattātreya: The Immortal Guru, Yogin, and Avatara-A Study of the Transformative and Inclusive Character of a Multi-Faceted Hindu Deity. Albany: State University of New York Press.

Ruegg, David Seyfort. 2007. The Symbiosis of Buddhism with Brahmanism/Hinduism in South Asia and of Buddhism with "Local Cults" in Tibet and the Himalayan Region. Österreichische Akademie der Wissenschaften, Philosophisch-Historische Klasse, Sitzgunsberichte; Vienna: Österreische Akademie Der Wissenschaften, vol. 774 .

Sanderson, Alexis. 1994. Vajrayāna: Origin and Function. In Buddhism into the Year 2000. Edited by Dhammakaya Foundation. Bangkok and Los Angeles: Dhammakaya Foundation, pp. 87-102.

Sanderson, Alexis. 2007. Atharvavedins in Tantric Territory: The Äंrgirasakalpa Texts of the Oriya Paippalādins and their Connection with the Trika and Kālikula. With critical editions of the Parājapavidhi, the Parāmantravidhi, and the *Bhadrakālìmantravidhiprakaraṇa. In The Atharvaveda and Its Paippalādaśākhā: Historical and Philological Papers on a Vedic Tradition. Edited by Arlo Griffiths and Annette Schmiedchen. Indologica Halensis 11; Aachen: Shaker, pp. 195-312.

Sanderson, Alexis. 2009. "The Śaiva Age-The Rise and Dominance of Śaivism during the Early Medieval Period". In Genesis and Development of Tantrism. Edited by Shingo Einoo. Tokyo: Institute of Oriental Culture, University of Tokyo, pp. 41-350.

Sax, William S. 2009. God of Justice: Ritual Healing and Social Justice in the Central Himalayas. Oxford and New York: Oxford University Press.

Scholem, Gershom Gerhard. 1991. Origins of the Kabbalah. Edited by R. J. Zwi Werblowsky. Translated by Allan Arkush. Princeton: Princeton University Press.

Schubring, Walter. 1978. Nayadhammakahao: Das Sechste Ange des Jaina-Siddhanta: Einführung, kritische Nacherzählung mit Ausgabe der wichtigern Textpartien, Kommentar und Glossar. Wiesbaden: In Kommission bei F. Steiner.

Sen, Sukumar. 1968. On Mūradeva, Mūladeva and Śiṣnādeva. In Méanges d'Indianisme a la Mémoire de Louis Renou. Publications de l'Institut de Civilisation Indienne, fasc. 28; Paris: Éditions E. de Boccard, pp. 677-81.

Serbaeva, Olga. 2013. Can Encounters with Yoginīs in the Jayarathayāmala Be Described as Possession? In "Yoginī" in South Asia: Interdisciplinary Approaches. Edited by István Keul. London: Routledge, pp. 198-212.

Shah, Tahir. 1998. Sorcerer's Apprentice. London: Weidenfeld and Nicolson.

Sica, Alan. 2000. Rationalization and culture. In The Cambridge Companion to Weber. Edited by Stephen Turner. New York: Cambridge University Press, pp. 42-58.

Siegel, Lee. 1991. Net of Magic: Wonders and Deceptions in India. Chicago and London: University of Chicago Press. Sinha, Shashank S. 2006. Adivasis, Gender and the 'Evil Eye': The Construction(s) of Witches in Colonial Chotanagpur. The Indian Historical Review 23: 127-49. [CrossRef]

Skilling, Peter. 2007. Zombies and Half-Zombies: Mahāsūtras and Other Protective Measures. Journal of the Pali Text Society 29: 313-30.

Stark, Rodney. 2015. Sociology of Religion: a Rodney Stark Reader. Waco: Baylor University Press. 
Sullivan, Bruce M. 2006. Tantroid Phenomena in Early Indic Literature: An Essay in Honor of Jim Sanford. Pacific World: Journal of the Institute of Buddhist Studies 8: 9-20.

Sweeney, Marvin A., and Ehud Ben Zvi. 2003. The Changing Face of Form Criticism for the Twenty-First Century. Grand Rapids: W. B. Eerdmans.

Tan, Randall K. J. 2001. Recent Developments in Redaction Criticism: From Investigation of Textual Prehistory Back to Historical-Grammatical Exegesis? Journal of the Evangelical Theological Society 44: 599-614.

Tarabout, Gilles. 2000. 'Passions' in the Discourses on Witchcraft in Kerala. Journal of Indian Philosophy 28: 651-64. [CrossRef]

Udayaadithya, A., and Angula Gurtoo. 2013. Governing the local networks in Indian agrarian societies-An MAS perspective. Computational and Mathematical Organization Theory 19: 204-31. [CrossRef]

Van Buitenen, Hans. 1958. The Indian Hero as Vidyādhara. The Journal of American Folklore 71: 305-11. [CrossRef]

Von Schiefner, F. Anton. 1906. Tibetan Tales Derived from Indian Sources-Translated from the Tibetan of the Kah-Gyur. Edited and translated by W. R. S Ralston; London: Kegan Paul, Trench, Trübner \& Co.

Weber, Max. 2001. The Protestant Ethic and the Spirit of Capitalism. Translated by Talcott Parsons. London and New York: Routledge Classics. First published 1930.

Weber. 1965. Sociology of Religion. Translated by Ephraim Fischoff. London: Methuen \& Co., Ltd. First published 1956.

Wedemeyer, Christian K. 2013. Making Sense of Tantric Buddhism: History, Semiology, E Transgression in the Indian Traditions. New York: Columbia University Press.

White, David Gordon. 2009. Sinister Yogis. Chicago and London: University of Chicago Press.

White, David Gordon. 2013. Ḍākinī, Yoginī, Pairikā, Strix: Adventures in Comparative Demonology. Southeast Review of Asian Studies 35: 7-31.

Whitney, William Dwight. 1905. Atharva-Veda Samithā: Translated with a Critical and Exegetical Commentary. Harvard Oriental Series; Vols 7-8, Cambridge, Mass: Harvard University Press.

Wujastyk, Dominik. 1984. An Alchemical Ghost: The Rasaratnākara by Nāgārjuna. Ambix 31: 70-83. [CrossRef] [PubMed]

Yamano, Chieko. 2013. The Yakṣin̄i-sādhana in the Kakṣaputa-tantra: Introduction, Critical Edition and Translation. Journal of the International College for Postgraduate Studies 17: 61-99.

Yisraeli, Oded. 2016. Jewish Medieval Traditions concerning the Origins of the Kabbalah. The Jewish Quarterly Review 106: 21-41. [CrossRef] 